\title{
Eliminating Electricity Deficit through Energy Efficiency in India: An Evaluation of Aggregate Economic and Carbon Benefits
}

\author{
Jayant Sathaye and Arjun P. Gupta \\ International Energy Studies Group \\ Lawrence Berkeley National Laboratory \\ Berkeley, CA 94720
}

30 April 2010

This work was supported by the US State Department and the ClimateWorks Foundation through the US Department of Energy under Contract No. DE-AC02$05 \mathrm{CH} 11231$. 



\section{Table of Contents}

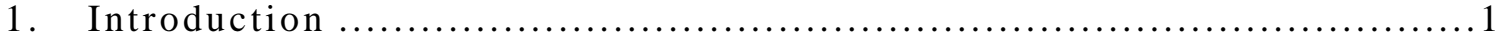

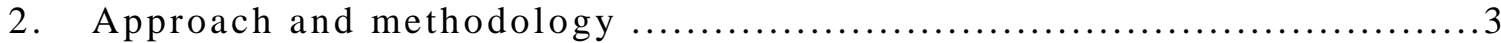

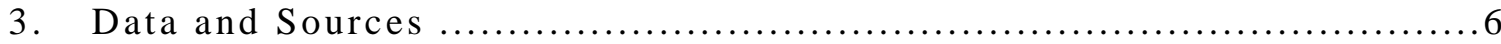

3.1 Construction, Fuel and O\&M Costs of Power Plants ........................6

3.2 Data Sources for Scenario 2: Electricity Efficiency Potential and Costs 7

3.3 Industrial and Commercial Businesses: .................................... 10

4. Electric Power Demand and Supply Scenarios ........................... 11

4.1 Business as Usual (BAU) Supply Scenario (Scenario 1): ..................12

4.2 Supply with Energy Efficiency Scenario (SEE, Scenario 2):..............14

5. Economic Benefits, and Fuel and $\mathrm{CO}_{2}$ Savings ...........................17

5.1 Capital, Variable Cost, Fuel, and $\mathrm{CO}_{2}$ Savings ........................... 17

5.2 Macro-economic Impacts: GDP Benefit.................................. 18

6. Limitations of the analysis ................................................ 23

7. Summary and Conclusions ............................................. 24

\section{Table of Figures}

Figure 1: Electricity shortage per peak MW deficit .............................

Figure 2: Comparative Growth in the Power Sector .............................

Figure 3: Business as Usual (BAU) Scenario 1 - Peak Load and Supply......4

Figure 4: Supply with Energy Efficiency (SEE) Scenario 2 - Peak Load and

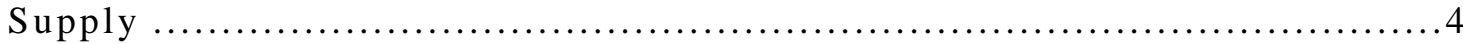

Figure 5: Commercial and LV-MV Industrial Sector Value Added .............11

Figure 6: Trend of Annual Capacity (MW) Addition (2002-2007) .............13

Figure 7: Peak-Load Saving Potential in the SEE Scenario .................... 14

Figure 8: Electricity Savings Potential..................................... 15

Figure 9: Business as Usual (BAU) Scenario 1 - Electricity Demand and Availability ............................................................ 16

Figure 10: Supply with Energy Efficiency (SEE) Scenario 2- Electricity Demand and Availability ..................................................... 16

Figure 11: Commercial and LV-MV Industry Electricity Shares ................19

Figure 12: Electricity Productivity (Commercial and LV-MV Industrial Sectors and Overall Economy) .......................................... 20

Figure 13: Inverter and Generator Stock : Historical and Projected ...........22 22

\section{Table of Tables}

Table 1: BAU Scenario Capacity Addition and Capital Costs ....................6

Table 2:Variable (Fuel and O\&M) Costs of Electricity Generation ..............7

Table 3: Fuel Requirement for Electricity Generation ........................

Table 4: Energy Consumption and Costs: Data and Estimates for Selected

Energy Efficiency Options ................................................ 9

Table 5: Matching of Value Added and Electricity Consumption Data........10 10

Table 6: 17th EPS Projections.................................................. 12

Table 7: Cumulative Benefits of SEE Scenario Compared to BAU Scenario 17 


\title{
Eliminating Electricity Deficit through Energy Efficiency in India:
}

\section{An Evaluation of Aggregate Economic and Carbon Benefits}

\author{
Jayant Sathaye and Arjun P. Gupta \\ International Energy Studies Group \\ Lawrence Berkeley National Laboratory \\ Berkeley, CA 94720
}

\begin{abstract}
Electricity demand has consistently exceeded available supply in India. While the electricity deficit varies across states, nationally it was estimated to be of the order of $12 \%$ on peak and $11 \%$ for electricity during 2008-09. This paper explores a demand-side focused potential for energy efficiency improvement to eliminate the electricity deficit compared to a business as usual (BAU) supply-side focused scenario. The limited availability of finance and other legal and administrative barriers have constrained the construction of new power plant capacity in India. As a result, under the BAU scenario, India continues to face an electricity deficit beyond the end of the Twelfth Five Year Plan. The demand-side cost-effective potential achieved through replacement of new electricity-using products, however, is large enough to eliminate the deficit as early as 2013 and subsequently reduce the future construction of power plants and thus reduce air pollutant emissions.

Moreover, energy efficiency improvements cost a fraction of the cost for new supply and can lead to a substantial increase in India's economic output or gross domestic product (GDP). Eliminating the deficit permits businesses that have experienced electricity cutbacks to restore production. We estimate the size of the cumulative production increase in terms of the contribution to GDP at a \$505 billion between 2009 and 2017, the end of India's Twelfth Five Year Plan, which may be compared with India's 2007-08 GDP of \$911 billion. The economic output is influenced by the size of the electricity savings and rate of penetration of energy efficient technologies, and that of self-generation equipment and inverters used by businesses faced with electricity cuts. Generation and inverters are estimated to service 23\% of these customers in 2009, which increase to $48 \%$ by 2020 . The reduction in the construction and operation of new power plants reduces the cumulative $\mathrm{CO}_{2}$ emissions by $65 \mathrm{Mt}$, and those of sulfur dioxide and nitrogen oxides by $0.4 \mathrm{Mt}$ each, while also reducing India's imports of coal and natural gas. By 2020, the cumulative GDP benefit increases to $\$ 608$ billion, the $\mathrm{CO}_{2}$ savings expand to $333 \mathrm{Mt}$ and $\mathrm{SO}_{2}$ and $\mathrm{NO}_{\mathrm{x}}$ to $2.1 \mathrm{Mt}$.
\end{abstract}




\section{Introduction}

Government utility companies, with only three major private sector generation and distribution companies, traditionally ran the Indian electric power sector until the mid 1990s. Since then the Indian government has pursued a policy of deregulation by opening it to private sector investment and separating generation from transmission and distribution of electricity. While there were many goals, a primary objective of this policy was to ensure a reliable supply of electricity to consumers at affordable prices. Deregulation was intended to reduce or eliminate the electricity deficit, improve the financial performance of the State Electricity Boards (SEBs), and reduce the government's outlay for construction of new electricity supply and subsidies. After almost two decades of reforms, however, the supply and demand gap of electricity widened over the years. In 1990-91, the electrical energy deficit was around $7.7 \%$, and by 2008-09 it grew to $11.1 \%$. The peak power deficit, however, reportedly declined from around $18 \%$ in $1990-91$ to $11.9 \%$ by $2008-09$ (CEA, 2009). Figure 1 shows that electricity shortage has increased faster than the peak power deficit, implying that the shortage is spreading over more hours per day.

Figure 1: Electricity shortage per peak MW deficit

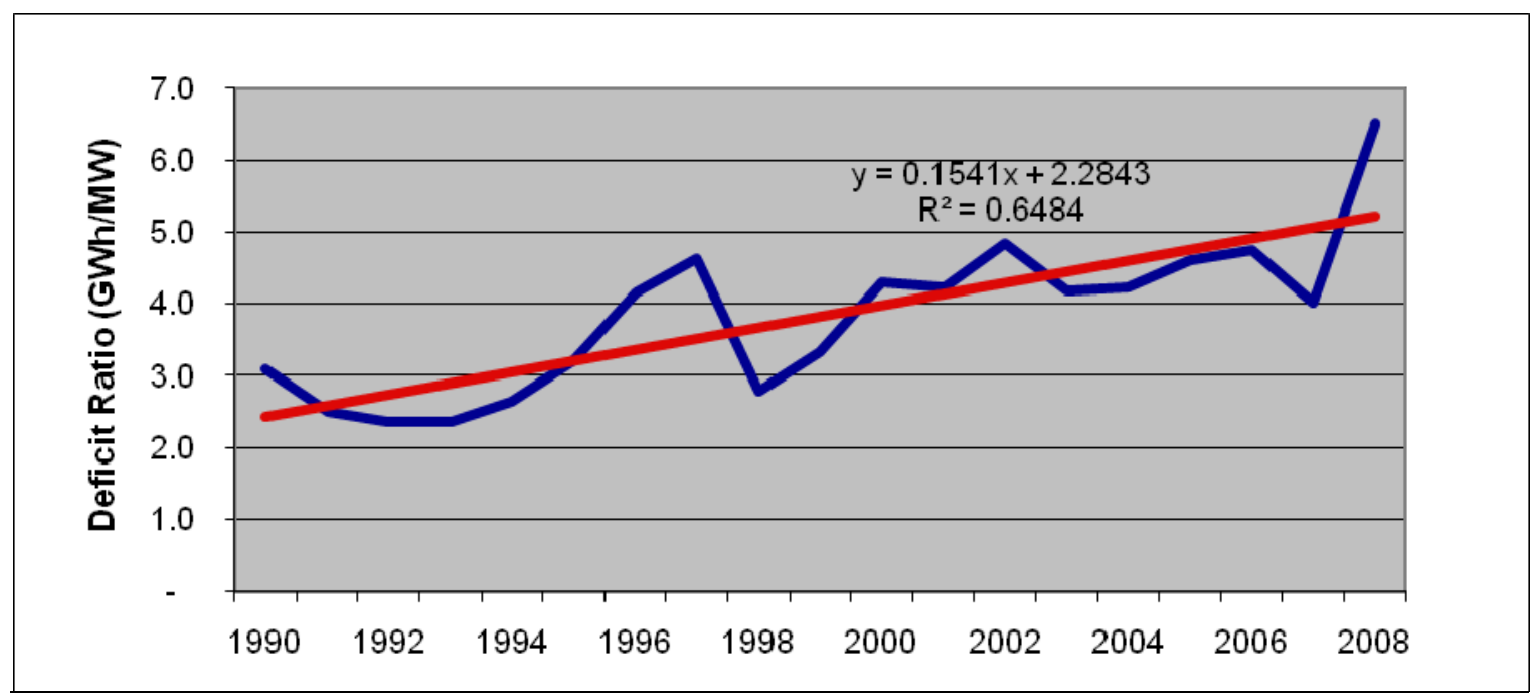

In part, this persistent deficit is due to the significant slippage in the generation expansion programs in the 9th and 10th Plan periods. The planned construction in the 9th Plan was for a capacity of $40.2 \mathrm{GW}$ while only $19.0 \mathrm{GW}$, less than $50 \%$, was built during this period (Planning Commission, 2002). The actual construction of capacity fell well short of the planned capacity in both the public and private sectors. The situation was similar during the 10th Plan when only 21.1 GW out of a planned 41.1 GW from conventional sources, slightly more than $50 \%$, was actually built (Planning Commission, 
2008) ${ }^{1}$. To further highlight India's difficulty in installing power capacity, Figure 2 shows that installed power capacity and per capita electricity consumption have increased slower than GDP since the $7^{\text {th }}$ Plan.

Figure 2: Comparative Growth in the Power Sector

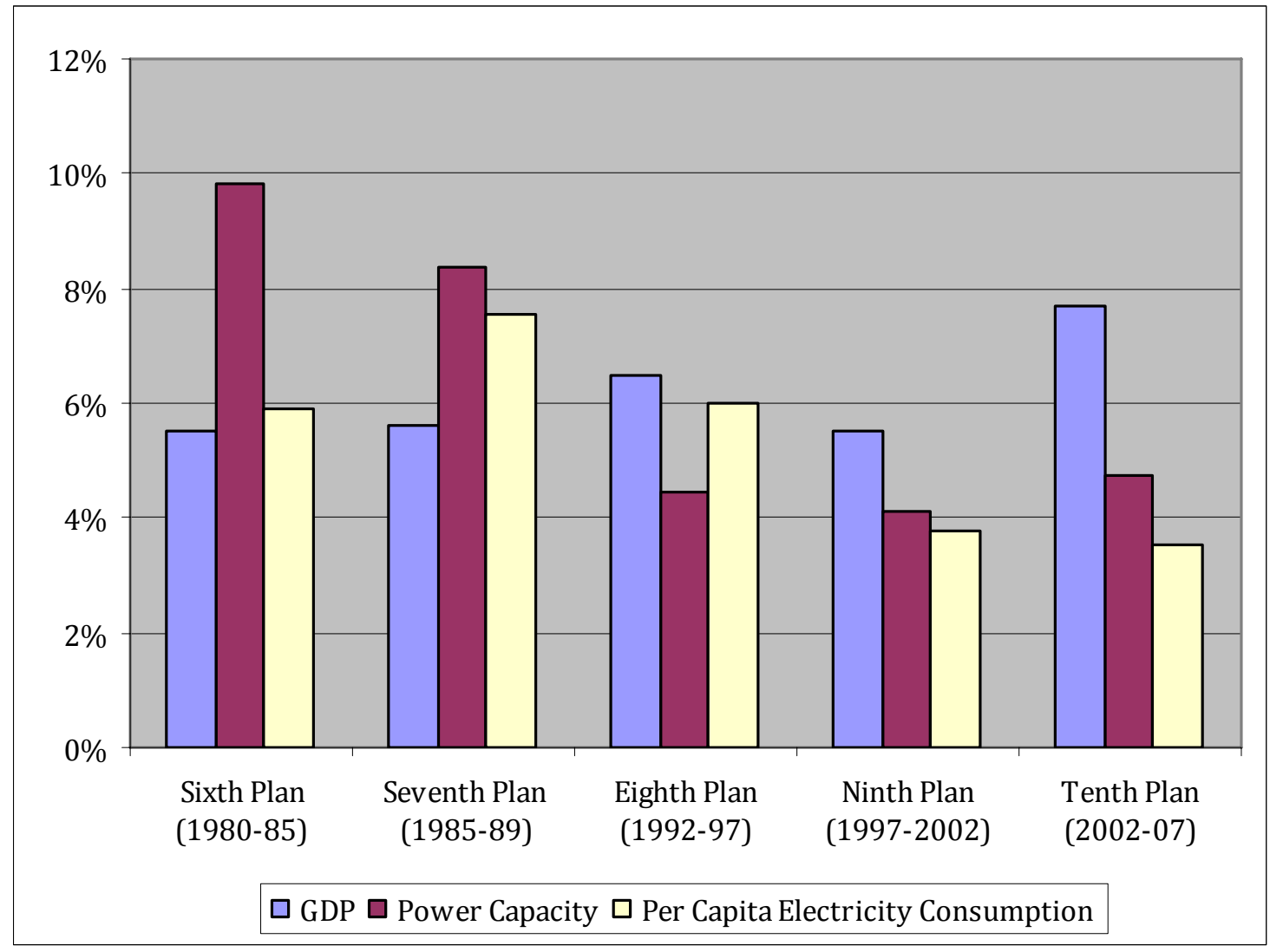

Source: Planning Commission (2008); CEA (2009)

In addition to a failure in meeting demand, electricity supply in India entails a significant financial burden on the national and state governments since electricity is heavily subsidized for the agricultural and domestic sectors. The gross subsidy amounted to Rs. 431 billion in 2007-08 or about US \$ 9.2 billion $^{2}$. Some SEBs are not compensated for providing such subsidies, which reached alarming levels in 2004-05 of approximately $26 \%$ in Rajasthan and greater than $20 \%$ in Karnataka and Haryana, as a percentage of their total revenues (MoP, 2007). The $10^{\text {th }}$ Plan outlay for the power sector in India was $11.1 \%$ of the total plan outlay, but an even larger proportion (13.2\%) of the states' plan outlay has been for the power sector (Planning Commission, 2008). Despite a substantial fraction of the government budget being devoted to the power sector, electricity deficits continue to persist.

\footnotetext{
${ }^{1}$ The numbers including renewable energy sources were $44.2 \mathrm{GW}$ and $27.9 \mathrm{GW}$ respectively.

${ }^{2}$ Economic Survey of India 2007-08. The exchange rate used in this paper is $47 \mathrm{Rs} / \mathbf{\$}$.
} 
The fiscal deficit in India has been and continues to be among the highest in the world. Though it reduced from a high of $6.2 \%$ of GDP in 2001-02 to around $3.2 \%$ in 2007-08, the good work got decisively reversed in 2008-09 with the fiscal deficit touching an alarming level of $7.8 \%$ of GDP against an initial target of $2.5 \%$ (Rediff Business, 2009).

In the context of this troubled background of the subsidy-plagued electric power sector and a high government fiscal deficit, an accelerated program to promote energy efficiency could provide significant benefits besides elimination of the electricity deficit. This will succeed in holding the investment outlays to the electric power sector no more (and potentially even less) than have been planned to date. The benefits of electricity efficiency have been recognized in the $10^{\text {th }}$ and $11^{\text {th }}$ Plans as they both emphasize its importance and outline measures for its implementation. Schemes for promoting energy efficiency in India during the $11^{\text {th }}$ Plan include the Bachat Lamp Yojana (promoting the uptake of CFLs), Standards and Labeling Scheme (covering all basic household appliances as well as motors, variable speed drives and agricultural pump sets), Energy Conservation Building Codes (for new commercial construction), Agricultural and Municipal DSM Schemes, and others. The $11^{\text {th }}$ Plan recognizes that restructuring incentives and support by shifting from supply driven programs to demand driven programs and technologies would be beneficial. The India Planning Commission has recognized strengthening of the Bureau of Energy Efficiency (BEE) as a priority and regulatory commissions in many states have started seriously considering demand side options. Hence, aggressive steps for the promotion of efficiency measures are expected during the $12^{\text {th }}$ Plan as well.

Recognizing the importance of energy efficiency options, this paper examines the aggregate economic output and $\mathrm{CO}_{2}$ reduction benefits from removing the electricity deficit through increased penetration of cost-effective energy efficient technologies. Section 2 outlines the approach and methodology used in estimating these benefits. Section 3 describes the data and sources used in the analysis. Section 4 discusses the two scenarios for reducing the electricity deficit in detail. Section 5 focuses on the economic and carbon dioxide benefits of the supply with efficiency scenario. Section 6 focuses on the limitations of the data and results and Section 7 describes the key conclusions.

\section{Approach and methodology}

In order to evaluate the potential for energy efficiency improvement and its impact on reducing the electricity deficit, we develop two scenarios, a business as usual (BAU) electricity supply scenario (BAU Scenario 1 ) and a supply with energy efficiency scenario (SEE Scenario 2). Each of these scenarios includes projections of peak power and electricity supply and demand. Figure 3 illustrates the BAU supply scenario in which peak power supply falls short of demand, and Figure 4 illustrates the SEE scenario with efficiency improvements so that not only does supply match and, over time, exceed demand but the quantity of supply is less than in the BAU scenario. The net result is that the total electricity supply and hence investment in the SEE scenario is less than in the BAU scenario. The SEE scenario also leads to higher business activity as businesses that face electricity shortages in the BAU scenario have electricity supply that is adequate to increase their output. 
Figure 3: Business as Usual (BAU) Scenario 1 Peak Load and Supply

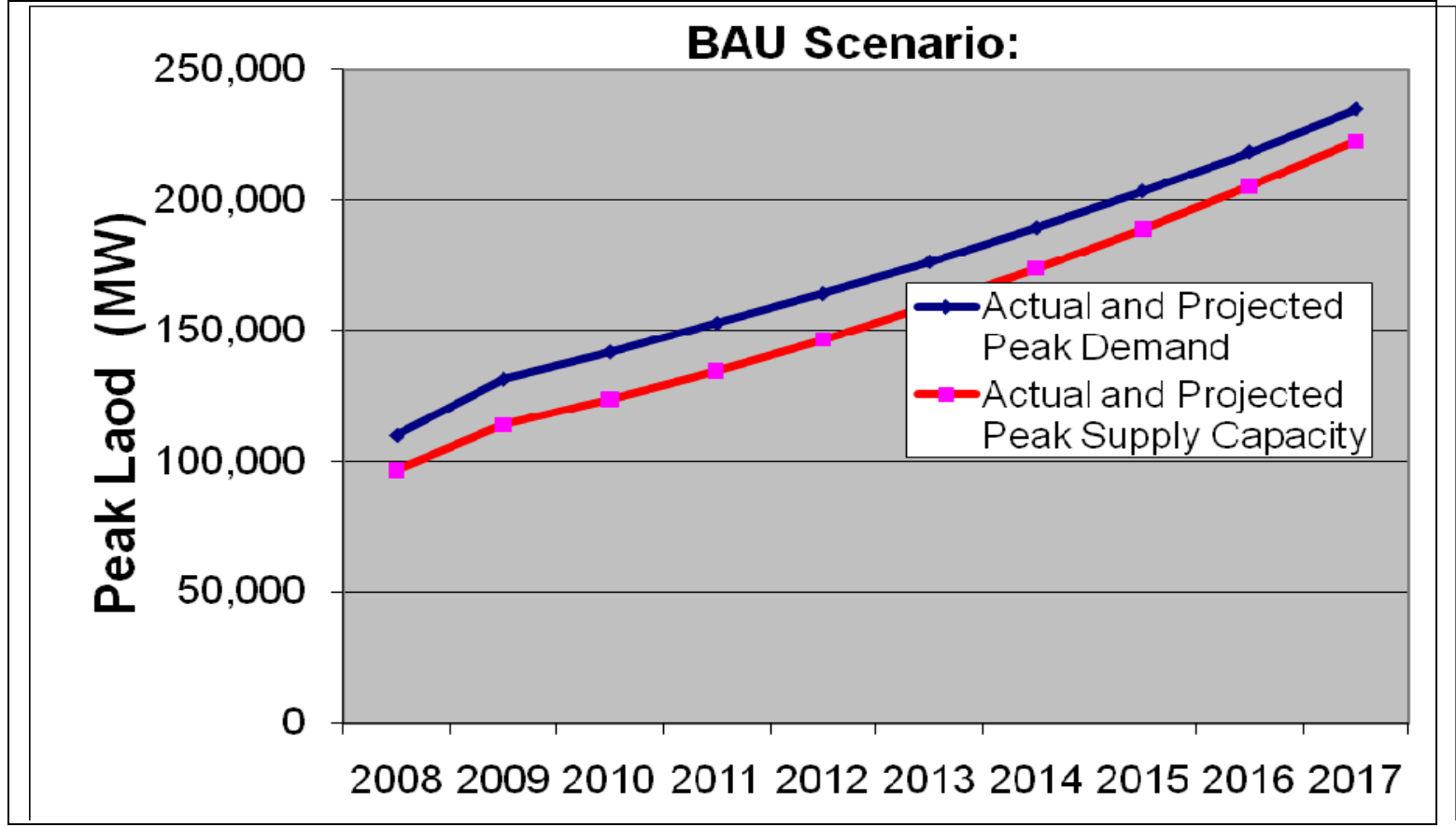

Figure 4: Supply with Energy Efficiency (SEE) Scenario 2 Peak Load and Supply

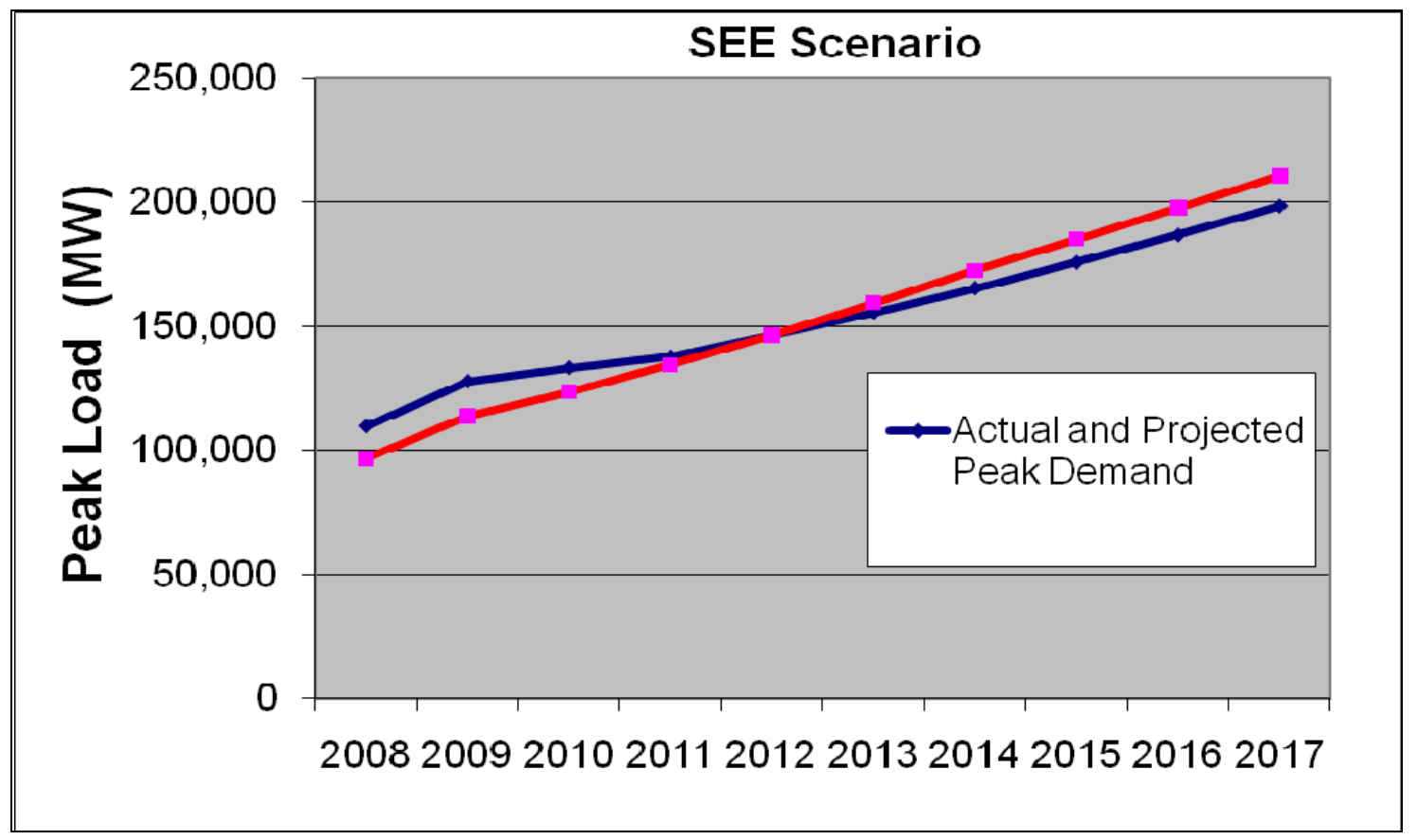


In order to compare the two scenarios, whose time line includes both the $11^{\text {th }}$ and $12^{\text {th }}$ Five Year Plans stretching from 2009 to 2017, we developed a bottom-up energy efficiency spreadsheet model. The model compares the power and electricity supply and demand over the aforementioned time period. For the BAU scenario, the model projects electricity demand and supply using data from the two Five Year Plans and CEA. For the SEE scenario, we estimate the potential power and energy requirement that would be offset by cost effective energy efficiency options over the same period. Only replacement and new sales options are included in the assessment; retrofitting existing technologies is excluded. The use of efficiency options results in a lower demand for electricity and power in the SEE scenario, which reduces the need for new capacity relative to that in the BAU scenario. The power deficit is thus reduced considerably in the SEE scenario and as seen in Figure 4, construction of new power plants is sufficient to eliminate the power deficit by 2012.

We estimate the capital investment needed for construction of new power plants in both scenarios. In the SEE scenario less capital is needed for new power plants but some capital is also needed for efficiency technologies. Because energy efficiency technologies are less capital intensive, the combined capital requirement for the SEE scenario is however lower than that for the BAU scenario. Since the primary emphasis in this paper is on investigating the role of energy efficiency, we model the demand-side technologies in detail by characterizing the techno-economics of 11 end-use applications. These are illustrated in Table 4 and include CFLs, efficient fluorescent tubelights, refrigerators, fans, room ACs, TVs, agricultural pumping, public water works, and industrial motors and processes The supply component of the scenarios, on the other hand, is modeled using a single composite technology that is representative of thermal, hydro, nuclear, wind and other smaller capacity power plants.

The projected peak load and capacity (Figures 3 and 4), and the consequent electricity generation, in the SEE scenario are lower than those in the BAU scenario despite the higher level of total electricity service provided in the former scenario. This reduced requirement for electricity generation results in reduced demand for imported coal and natural gas fuels and lower emissions of pollutants including carbon dioxide, and reduced operational costs (including fuel and O\&M costs) of power plants. We estimate and include these benefits in the results reported in Section 5.

The additional electricity service available in the SEE scenario is assumed to be utilized by energy constrained sectors that would otherwise have experienced power cuts - domestic, commercial and LV-MV industrial (CEA, 2006a). We estimate the increase in production owing to the removal of the electricity shortage to the productive (commercial and LV-MV industrial) sectors. We assume that electricity shortage implies that other factors of production are present and that availability of electricity would allow businesses to make full use of other inputs to production. Because of the long-term electricity shortage many businesses already rely on diesel or gasoline generators and inverters. We account for these in estimating the impact on overall sector output.

An earlier analysis of direct and indirect income and employment impacts between the two scenarios showed that the difference in impacts between the two 
scenarios is small (Sathaye et al. 2006). Because the capital investment is held constant in the two scenarios, the difference arises only because of the variation in investment in different sectors of the economy, and the variation in sector income and employment multipliers. Since the sector multiplier values are very similar, the difference in impacts between the two scenarios is much smaller than would be the case otherwise. We have therefore chosen not to report these benefits in this paper.

\section{Data and Sources}

Data on construction and fuel and O\&M costs, lifetimes of power plants electricity efficiency options, and estimates of the potential savings from the latter, were gathered on the basis of information available for specific options from the Indian government and/or that available through published literature. Since the analysis is performed from a societal perspective, we use a societal discount rate of $10 \%$ for India.

\subsection{Construction, Fuel and O\&M Costs of Power Plants}

This sub-section presents the data used for these items in both the BAU and SEE scenarios. The construction cost data for thermal and hydro power plants are based on CEA's current estimates of construction costs, and checked against the construction costs of some recently commissioned plants (CEA, 2009b). The capital costs of renewablebased power plants vary substantially - wind plants cost Rs 4.50 crore (\$ 0.96 million) per MW while small hydro power plants cost Rs 5.50 crore (\$1.2 million) per MW (Planning Commission, 2008). Other renewable-based plants also cost more than wind power plants. However, since wind constitutes the majority of planned capacity addition from renewables (90\% during the $11^{\text {th }}$ Plan), we use Rs 4.60 crore ( $\$ 0.98$ million) per MW as the representative capital cost for renewable-based power plants. The capital costs of nuclear plants also vary considerably. We thus use the construction cost of the latest nuclear plant (Kaiga I \& II) as the benchmark (Ramana et al, 2005). Table 1 presents the results:

Table 1: BAU Scenario Capacity Addition and Capital Costs

\begin{tabular}{|l|r|r|}
\hline $\begin{array}{l}\text { Sector } \\
(2009-2017)\end{array}$ & $\begin{array}{c}\text { Addition to Installed } \\
\text { Capacity (MW) }\end{array}$ & $\begin{array}{c}\text { Cost } \\
\text { (Rs crore/MW; \$ million/MW) }\end{array}$ \\
\hline Thermal & 63,505 & $4.15 ; 0.88$ \\
\hline Hydro & 34,656 & $4.86 ; 1.03$ \\
\hline Nuclear & 14,180 & $6.58 ; 1.40$ \\
\hline RES & 28,559 & $4.60 ; 0.98$ \\
\hline Total Installed Capacity & 140,900 & $4.66 ; 0.99$ \\
\hline
\end{tabular}

The composite technology is thus modeled as having a capital cost of Rs 4.66 crore per MW, or US $\$ 992$ per kW.

The generation of electricity is lower in Scenario 2. In order to quantify the benefits due to reduced generation, we need to know the reduced amount of fuel use and operational costs of power plants - coal, gas, hydro and nuclear. The costs are allocated based on their current shares of generation. We combine these numbers with estimates 
from CEA of the variable costs of generation using each of these technologies (CEA, 2009a). We present the averages of such costs for each technology in Table 2.

Table 2:Variable (Fuel and O\&M) Costs of Electricity Generation

\begin{tabular}{|l|r|}
\hline \multicolumn{1}{|c|}{ Technology } & Variable costs (Rs/kWh; US cents/kWh) \\
\hline Coal & $2.03 ; 4.32$ \\
\hline Gas & $2.33 ; 4.96$ \\
\hline Hydro & $1.80 ; 3.83$ \\
\hline Nuclear & $2.10 ; 4.47$ \\
\hline
\end{tabular}

Source: CEA (2009a)

Savings in fuel costs constitute a substantial part of these savings. In 2006-07, India imported 23 million tons of thermal coal for power generation. Additionally, India is projected to import 25 billion standard cubic meters (SCM) of gas during 2011-12 despite a large expected increase in domestic gas production in the Krishna-Godavari basin (Planning Commission, 2008). Reduction in electricity generation could thus yield significant energy security benefits. To estimate the reduction in import requirement of these fuels, we use the information presented in Table 3 below:

Table 3: Fuel Requirement for Electricity Generation

\begin{tabular}{|l|r|r|r|}
\hline Fuel & Calorific Value & $\begin{array}{c}\text { Efficiency of } \\
\text { Power Plants }\end{array}$ & $\begin{array}{c}\text { Fuel Requirement Per Unit of } \\
\text { Electricity Generation }\end{array}$ \\
\hline Imported Coal & $6665 \mathrm{kcal} / \mathrm{kg}$ & $31 \%$ & $0.42 \mathrm{~kg} / \mathrm{kWh}$ \\
\hline Gas & $9000 \mathrm{kcal} / \mathrm{SCM}$ & $43 \%$ & $0.22 \mathrm{SCM} / \mathrm{kWh}$ \\
\hline
\end{tabular}

\subsection{Data Sources for Scenario 2: Electricity Efficiency Potential and Costs}

Several studies report on the potential for electricity efficiency measures and their costs but detailed analyses of these parameters are not available in a consistent format. Analysis from 2002 shows a very large potential for six common end-uses that are also cost-effective (Deneb Consultants, 2002). The report also provides estimates of the investment requirements of these measures. Presentations from BEE and a paper from the World Resources Institute (WRI) provide more recent estimates of this potential (BEE, 2007; WRI, 2009). These sources, however, are not comprehensive enough for our purposes and/or relate to different timeframes.

The three most useful sources of information for our purposes is a recent report prepared by Prayas Energy Group (2009), a baseline model for the energy and $\mathrm{CO}_{2}$ emissions scenario for India up to 2020 prepared by Lawrence Berkeley National Laboratory (de la Rue du Can et. al., 2009), and a report by the Central Electricity Authority (CEA, 2009). The first report analyzes the data for individual end-uses for the residential sector. It includes current penetration levels of end-use technologies for lighting and appliances and also projects future increases by 2013 based on current sales data and the potential for efficiency improvements based on currently marketed most efficient technologies. The data show for instance that the sales of room air conditioners are increasing at $25 \%$ annually while the sales growth rate for lighting technologies is 
about $1 \%$. Sales of incandescent lamps are about double the stock since these have an average life of about six months. We take into account these data and project future sales up to 2017. For example for ACs we assume a lower sales growth rate of $15 \%$ since the demand growth is likely to stabilize over time whereas that for lighting we maintain the same 1\% growth rate. The data used in the analysis are illustrated in Table 4.

To estimate the connected loads for the industrial and municipal sectors, we scale up data from 2004-05 provided by the Central Electricity Authority (CEA) in their General Review report for 2006 (CEA, 2006). The table is organized by sector and the categories of appliances or processes that are targeted to reduce energy use. It shows the stock of appliances in 2008 and the estimated electricity consumption for each appliance or process. Motors and agricultural water pumping electricity uses are clearly larger than those for other applications. The subsequent columns include data on lifetime and estimated growth rates, hours of daily use and electric power savings potential for each category. Growth rates are based on current growth rates for relatively mature technologies but as noted above are lower than the $25 \%$ current rate for AC penetration of which has begun to increase relatively recently with rising incomes. Hours of use for the same device vary by sector, e.g., FTL usage is 5 hours per day for the residential sector but 8 hours per day for the commercial sector. The next column estimates the percentage savings, which are very large (75\%) for CFLs but small (5\%) for motors. The contribution of motors to gross savings is thus small despite their large use of electricity. Electricity (kWh/yr/unit) savings potential is calculated on the basis of usage per year and the wattage reduction for each category.

The next two columns show the total connected load and the fraction of the load that is estimated to occur during peak hours and thus contributes to the system peak load. Connected load for lighting is clearly very large as is the contribution to evening peak, and any improvement in efficiency of this end-use would significantly reduce the power deficit in the Indian grid system.

In addition to the above data on electricity consumption, connected load, and energy saving potentials, we need information on costs of these technologies. The cost per $\mathrm{kW}$ is expressed in 2007 US \$ in Table 4. We also compute the present value of the costs of these technologies. The present value estimate is based on the estimated lifetime of each piece of equipment. If it is less than nine years then the equipment may have to be replaced multiple times between 2009 and 2017. Residential CFLs that have an estimated life of 2.7 years would need to be replaced three times over the nine year period. The calculation also results in a different present value for TFLs that are used in the residential sector from those used in the commercial sector. The last column shows the connected load in 2009, which is based on the percentage of time that the load in each category occurs during the evening peak. 
Table 4: Energy Consumption and Costs: Data and Estimates for Selected Energy Efficiency Options

\begin{tabular}{|c|c|c|c|c|c|c|c|c|c|c|c|}
\hline Sector & Appliance / Process & $\begin{array}{l}2008 \\
\text { Stock of } \\
\text { Appliance } \\
\text { s } \\
\text { (Millions) }\end{array}$ & $\begin{array}{l}2008 \\
\text { Estimated } \\
\text { Electricity } \\
\text { Consumptio } \\
\text { n, (TWh/yr) }\end{array}$ & $\begin{array}{l}\text { Lifetim } \\
\text { e and } \\
\text { Growth } \\
\text { Rate } \\
\text { (yrs; \%) }\end{array}$ & $\begin{array}{l}\text { Hour } \\
\text { s of } \\
\text { Use } \\
\text { per } \\
\text { Day }\end{array}$ & $\begin{array}{l}\text { Electric } \\
\text { Power } \\
\text { Savings } \\
\text { Potential } \\
\text { (Watts/uni } \\
\text { t and/or \% } \\
\text { Savings) }\end{array}$ & $\begin{array}{l}\text { Electricity } \\
\text { Savings } \\
\text { Potential } \\
\text { (kWh/yr/uni } \\
\text { t or \% } \\
\text { Savings) }\end{array}$ & $\begin{array}{l}\text { Peak } \\
\text { Coincidenc } \\
\text { e Factor } \\
(\%)\end{array}$ & $\begin{array}{l}\text { Connecte } \\
\text { d Load } \\
2009 \\
\text { (MW) }\end{array}$ & $\begin{array}{l}\text { Capital Cost of } \\
\text { Estimated } \\
\text { Savings } \\
\text { (US } 2007 \\
\$ / k W)\end{array}$ & 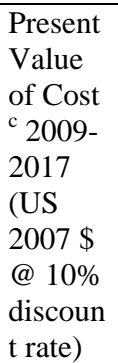 \\
\hline Res. & Incandescent Lamps (ICs) $^{b}$ & 301.64 & 26.42 & 2.1 & 4 & $45 ; 75 \%$ & 65.6 & $25 \%$ & 57,338 & 50 & 113 \\
\hline Res. & $\begin{array}{l}\text { Fluorescent Tubelights } \\
\text { (FTLs) }\end{array}$ & 280.27 & 25.06 & 2.7 & 5 & $21 ; 43 \%$ & 38.3 & $50 \%$ & 24,248 & 125 & 283 \\
\hline Res. & Refrigerators & 37.33 & 21.95 & $10 ; 10$ & 8 & $59 ; 29 \%$ & 171.0 & $33 \%$ & 5,893 & 800 & 661 \\
\hline Res. & Fans & 246.4 & 29.57 & $10 ; 10$ & 8 & $11 ; 27 \%$ & 32.0 & $50 \%$ & 14,728 & 534 & 441 \\
\hline Res. & Room ACs & 5.05 & 6.05 & $10 ; 15$ & 6 & $365 ; 29 \%$ & 263.0 & $50 \%$ & & 340 & 309 \\
\hline Res. & TV & 98.59 & 17.25 & $10 ; 10$ & 6 & $22 ; 37 \%$ & 48.0 & $75 \%$ & & 400 & 364 \\
\hline $\begin{array}{l}\text { Comm. } \\
\text { and } \\
\text { Muni. }\end{array}$ & T-5 FTLs & 140.14 & 20.05 & 1.7 & 8 & $21 ; 42 \%$ & 61.3 & $75 \%$ & 11,549 & 125 & 553 \\
\hline Ind. & Motors & & 123.25 & $15 ; 6$ & 11 & $5 \%$ & $5 \%$ & $25 \%$ & 62,292 & 275 & 227 \\
\hline Ind. & All Processes & & 52.82 & ;6 & 11 & $15 \%$ & $15 \%$ & $25 \%$ & 88,989 & 550 & 455 \\
\hline Agri. & Water Pumping & 15.8 & 104.15 & $15 ; 5$ & 4 & $\begin{array}{l}1463^{\mathrm{a}} ; \\
35 \%\end{array}$ & $2307.2^{\mathrm{a}}$ & $15 \%$ & 70,067 & 195 & 161 \\
\hline Muni. & Public Water Works & & 12.88 & $15 ; 4.5$ & 7.5 & $20 \%$ & $20 \%$ & $25 \%$ & 4,549 & 171 & 141 \\
\hline
\end{tabular}

Note: a: Savings per customer;

b: Incandescent lamps are replaced by Compact Fluorescent Lamps (CFLs)

c: We assume that for devices whose lifetime is less than 9 years, multiple purchases and investments would occur over the $2009-2017$ period, e.g. for CFLs three lamps would be purchased over this period since their estimated lifetime is 2.7 years.

Primary Sources: Residential: Prayas Energy Group (2009); Agriculture and Municipal Data from CEA (2009); Industry data from De la Rue du Can et al. (2009); Dutt, 1991;

BEE, 2007; WRI, 2009; Public Water Works: Barry, 2007, Natarajan 2008, WRI 2009. 


\subsection{Industrial and Commercial Businesses:}

In order to estimate the difference in macro-economic impacts between the two scenarios, we need to estimate the electricity productivity of the industrial and commercial sectors. For each sector, electric productivity is calculated by dividing the value added attributable to the sector by the sector's electricity consumption. In the absence of a single data source for these data, data on value added are taken from the Economic Survey of India (ESI) and statistics provided by the Ministry of Statistics and Program Implementation, while data on electricity consumption by sector are taken from several years of CEA data (CEA, 2009 and similar prior year reports). However, this necessary de-construction involves the following complications:

The electricity consumption categories reported by CEA are different from those used in reporting the value added by the ESI. This requires matching between the two data sets (see Table 5).

The industrial sector is made up of small and large industries and the latter are mostly supplied by high voltage or tension (HV) electricity, which is not subject to electricity cutbacks. It is therefore necessary to examine the distribution of $\mathrm{HV}$ and low and medium tension (LV-MV) electricity (see Table 5).

Table 5: Matching of Value Added and Electricity Consumption Data

\begin{tabular}{|l|l|}
\hline Value Added (ESI) & Electricity Consumption (CEA) \\
\hline Agriculture, Forestry and Fishing & Agriculture \\
\hline Mining and Quarrying & 50\% LV\&MV; 50\% HV \\
\hline & $\begin{array}{l}\text { Registered - HV; } \\
\text { Unregistered - LV\&MV }\end{array}$ \\
\hline Electricity Gas and water supply & HV \\
\hline Construction & LV\&MV \\
\hline Trade hotels and Restaurants & Commercial \\
\hline Storage and communication & Commercial \\
\hline Finance real estate insurance business services & Commercial \\
\hline & $\begin{array}{l}\text { Public Water Works and } \\
\text { Miscellaneous }\end{array}$ \\
\hline
\end{tabular}

Figure 5 shows the growth of value added for the LV-MV industrial and commercial sectors since 1990-91. We report changes since 1991 because India adopted a more liberalized economic policy that has continued since that period. 
Figure 5: Commercial and LV-MV Industrial Sector Value Added

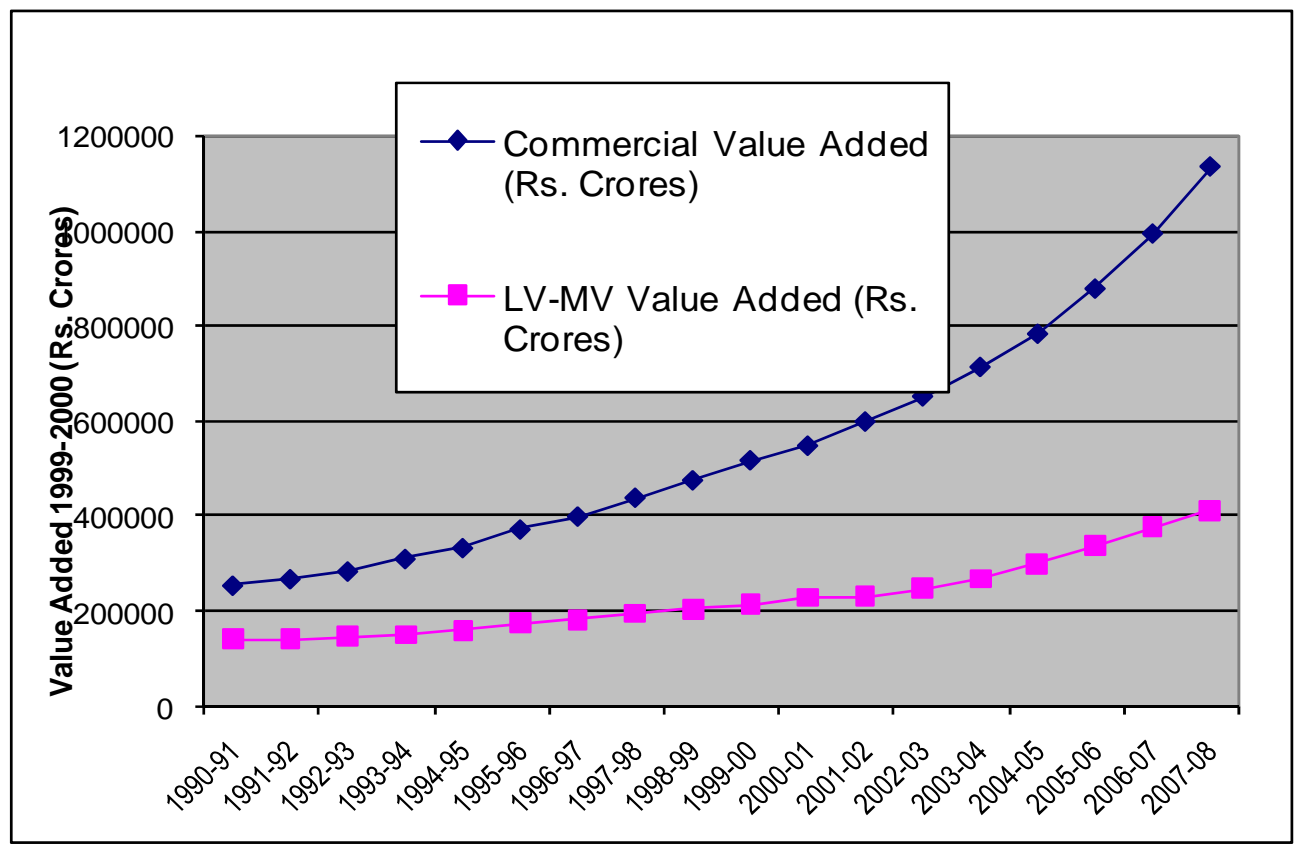

Source: Economic Survey of India 2007-08

\section{Electric Power Demand and Supply Scenarios}

The Electric Power Information Society under the Central Electricity Authority (CEA) publishes documents containing important information on the power sector in India. The report of the $17^{\text {th }}$ Electric Power Survey (EPS) of India is a publication giving forecasts of electricity demand, which serves as an important input for power sector planning to optimally utilize the nation's scarce resources. The Electric Power Survey Committee conducts periodic surveys of electricity demand and holds discussions with all the stakeholders to produce demand forecasts for use in planning exercises of all key sectors of the economy i.e. coal, rail, manufacturing, infrastructure, research, industries, etc. The $17^{\text {th }}$ EPS projects peak demand and the electrical energy requirement during 2016-17 (MoP, 2007a). In order to analyze the macroeconomic impacts of accelerated penetration of energy efficiency technologies, we construct two scenarios for the eightyear period from 2009 until $12^{\text {th }}$ Plan ending in 2017 for meeting this projected demand.

The first scenario (Supply) is Business as Usual (BAU). This is based on the trend of increasing achievement levels experienced during the five years of the $10^{\text {th }}$ Plan and the first year of the $11^{\text {th }}$ Plan, ${ }^{3}$ and checked against the capacity expansion figures as stated in the $11^{\text {th }}$ Plan $(92,577 \mathrm{MW})^{4}$ and preliminary estimates for the $12^{\text {th }}$ Plan

\footnotetext{
${ }^{3}$ Starting with the $1^{\text {st }}$ Five Year Plan, the planned electricity new capacity target has never been achieved. The achievement level in the $1^{\text {st }}$ Plan was $76 \%$, while those in the $9^{\text {th }}$ and $10^{\text {th }}$ Plans were $47 \%$ and $51 \%$.

${ }^{4}$ Including 14,000 MW from Renewable Energy Sources (RES)
} 
(122,171 MW) (Planning Commission, 2008). Peak demand and electrical energy requirement are still not met in this scenario.

A second scenario (Supply with Energy Efficiency, or SEE) is developed for the same period. ${ }^{5}$ This scenario includes increased penetration of end-use energy efficiency devices that thus reduce the need (through effective increase in supply of electricity service) for capacity expansion compared to the first scenario. To determine the potential for savings through efficiency improvements in Scenario 2, we estimate the proportion of the additional demand from now until 2017 that will be met with efficient appliances/processes. Additionally, we assume that all the appliances that will retire from the current stock until 2017 will be replaced with efficient ones. Since efficient technologies require less investment per kWh of electricity service, it is possible to meet the peak power demand and overall electricity requirement while holding investment at a level lower than in Scenario $1^{6}$.

The $17^{\text {th }}$ Electric Power Survey (EPS) of India projects that the peak demand in India during 2016-2017 would be in excess of $218 \mathrm{GW}$ while the demand for electricity generation would cross 1,392 TWh (CEA, 2006a). This assumes accomplishment of the goal of electrification of all households by 2011-12, significant improvements in T\&D loss reduction and a 5\% spinning reserve. It also includes demand reduction owing to the implementation of some DSM measures but since CEA does not publish any data on these measures, we consider these to be small enough to disregard them in our analysis. Assuming an $80 \%$ plant availability factor, the corresponding requirement for installed capacity is $273 \mathrm{GW}$. Table 6 presents the EPS projections:

Table 6: 17th EPS Projections

\begin{tabular}{|l|r|r|r|}
\hline 17th EPS & \multicolumn{1}{|c|}{$2009-10$} & $2011-12$ & \multicolumn{1}{|c|}{$2016-17$} \\
\hline Peak Demand (MW) & 131,413 & 152,746 & 218,209 \\
\hline Electrical Energy Requirement (EER) (TWh) & 848 & 968 & 1,392 \\
\hline Implied Load Factor (LF) & $74 \%$ & $73 \%$ & $72 \%$ \\
\hline T\&D Losses (\%) & $25 \%$ & $22 \%$ & $19 \%$ \\
\hline Electricity Consumption (EC) (TWh) & 636 & 755 & 1,128 \\
\hline
\end{tabular}

Source: CEA (2006a)

\subsection{Business as Usual (BAU) Supply Scenario (Scenario 1):}

In order to determine the likely capacity addition in the BAU scenario, we use data on actual capacity addition in previous years and on plans for future capacity addition. The numbers for capacity addition realized during the $10^{\text {th }}$ Plan and the first

\footnotetext{
${ }^{5}$ During the 1980s, several authors investigated the tradeoff between the costs of electricity deficits vs. those of increasing the reliability of electricity supply. For a collection of these papers, see Munasinghe M., Woo C., and Chao H (Eds.). 1988. Special Electricity Reliability Issue. The Energy Journal. Vol. 9.

${ }^{6}$ A draft McKinsey report titled "Powering India: The Road to 2017” projects that peak demand by 2017 would be between 315 and 335 MW (around 100GW higher than other projections). In this case, peak demand would not be met in the SEE Scenario 2 even if the entire investible fund from Scenario 1 was invested in this quest. The peak availability by 2017 in this case would be $235 \mathrm{GW}$ - a $28 \%$ shortage.
} 
year of the $11^{\text {th }}$ Plan are calculated from the CEA's report on growth of installed capacity since the $6^{\text {th }}$ Plan (CEA, 2009). Data for $10^{\text {th }}$ and $11^{\text {th }}$ Plan planned capacity addition as well as tentative capacity addition envisioned during the $12^{\text {th }}$ Plan are obtained from the Planning Commission and from CEA (Planning Commission, 2008; Bakshi, 2008). Data on peak power and energy deficit are taken from the 2007-08 annual report of the Ministry of Power (MoP, 2008) and from CEA's monthly power sector reports (CEA, 2009).

Figure 6 presents the trend of addition to capacity between 2002 and 2007. The pace of capacity addition increased significantly between 2002-03, when only 2,831 MW were added, and 2007-08, when 10,732 MW were added to installed capacity. The year 2008-09 witnessed only 5,204 MW of capacity addition, but from the trend observed during previous years, we do not expect such poor performance to be repeated.

Figure 6: Trend of Annual Capacity (MW) Addition (2002-2007)

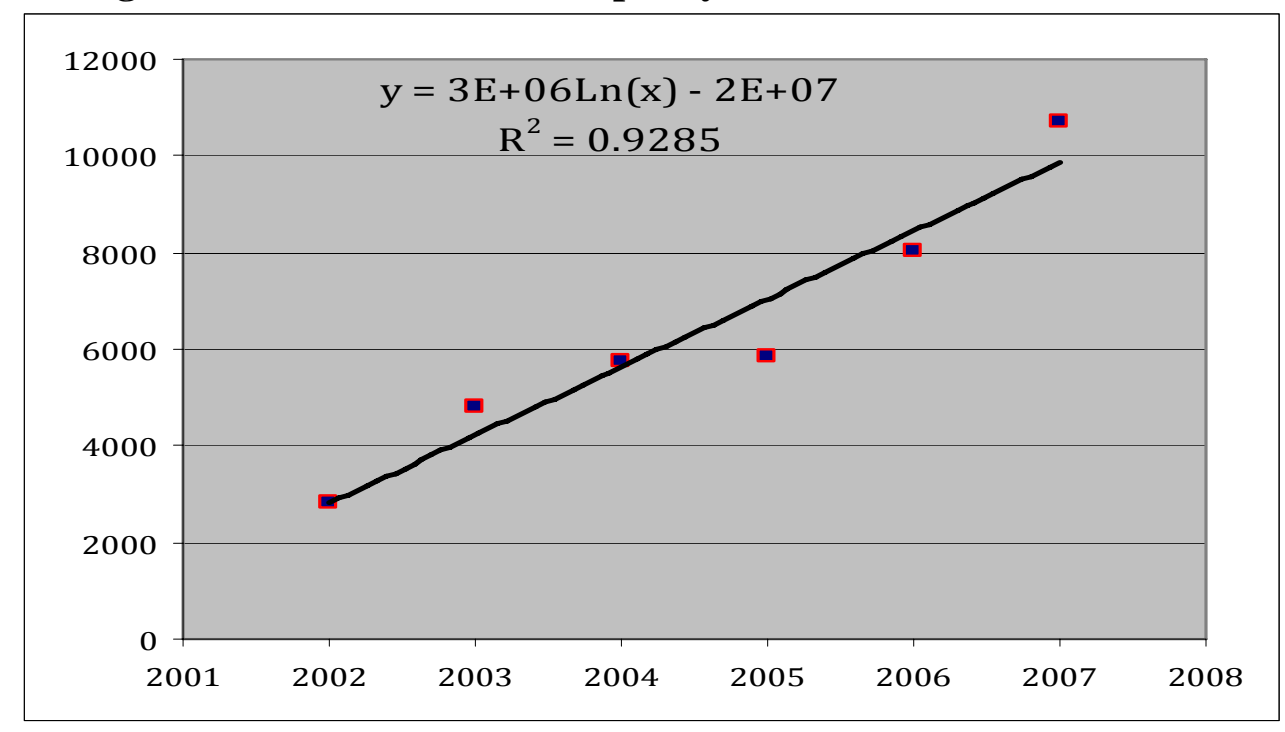

Source: Based on CEA (2009) data

We assume that this trend will continue into the future with annual capacity addition reaching a maximum close to 24,000 MW during 2016-17, the last year of our analysis period. The resulting capacity addition estimate for the remaining three years of the $11^{\text {th }}$ Plan is $42,300 \mathrm{MW}$ and for the entire $12^{\text {th }}$ Plan is $98,600 \mathrm{MW}$ summing to a total capacity addition of 140,900 MW in the BAU scenario.

Since we model capacity addition as a single composite technology in Scenario 2, we need to calculate a single number representing the capital cost of power plants. We thus need to disaggregate the overall capacity addition estimates by the type of technology. During the $10^{\text {th }}$ Plan, almost $100 \%$ of planned nuclear capacity addition and $218 \%$ of planned capacity addition from renewable sources were actually put in place. For the $11^{\text {th }}$ and $12^{\text {th }}$ Plans, we assume that $100 \%$ of planned capacity from these two sources will be put in place (since repeating the performance for renewables is unlikely). The remaining addition to power capacity comes from thermal and hydro power plants. We assume that the ratio between hydro and thermal technologies of achievement to 
planned capacity addition stays the same over our analysis period as during the $10^{\text {th }}$ Plan (128\%).

Based on above data and assumptions, the peak demand and peak capacity available at the bus bar for the first scenario (BAU Scenario) are shown in Figure 3. Peak demand and available peak capacity increases from $131 \mathrm{GW}$ to $234 \mathrm{GW}$ and from 114 GW to 222 GW respectively from 2009 to 2017. The electric power deficit is persistent in this scenario while gradually reducing from $13 \%$ to $5 \%$ by 2017 . The corresponding discounted cumulative investment for the power supply amounts to $\$ 81.4$ billion over this period.

The electricity generation and consumption in the scenario also are deficit prone. The deficit declines from 83 TWh in 2009 to 62 TWh by 2017. Since the load factors in the analysis do not change significantly over the study period the percentage deficit is the same as noted above in the power scenario.

\subsection{Supply with Energy Efficiency Scenario (SEE, Scenario 2):}

Using the data described in Section 3 above, we calculate the potential for peak reduction and electricity savings through the implementation of efficiency measures for all new demand and all retired appliances over an 8-year period until the end of the $12^{\text {th }}$ Plan in March 2017.

Figure 7: Peak-Load Saving Potential in the SEE Scenario

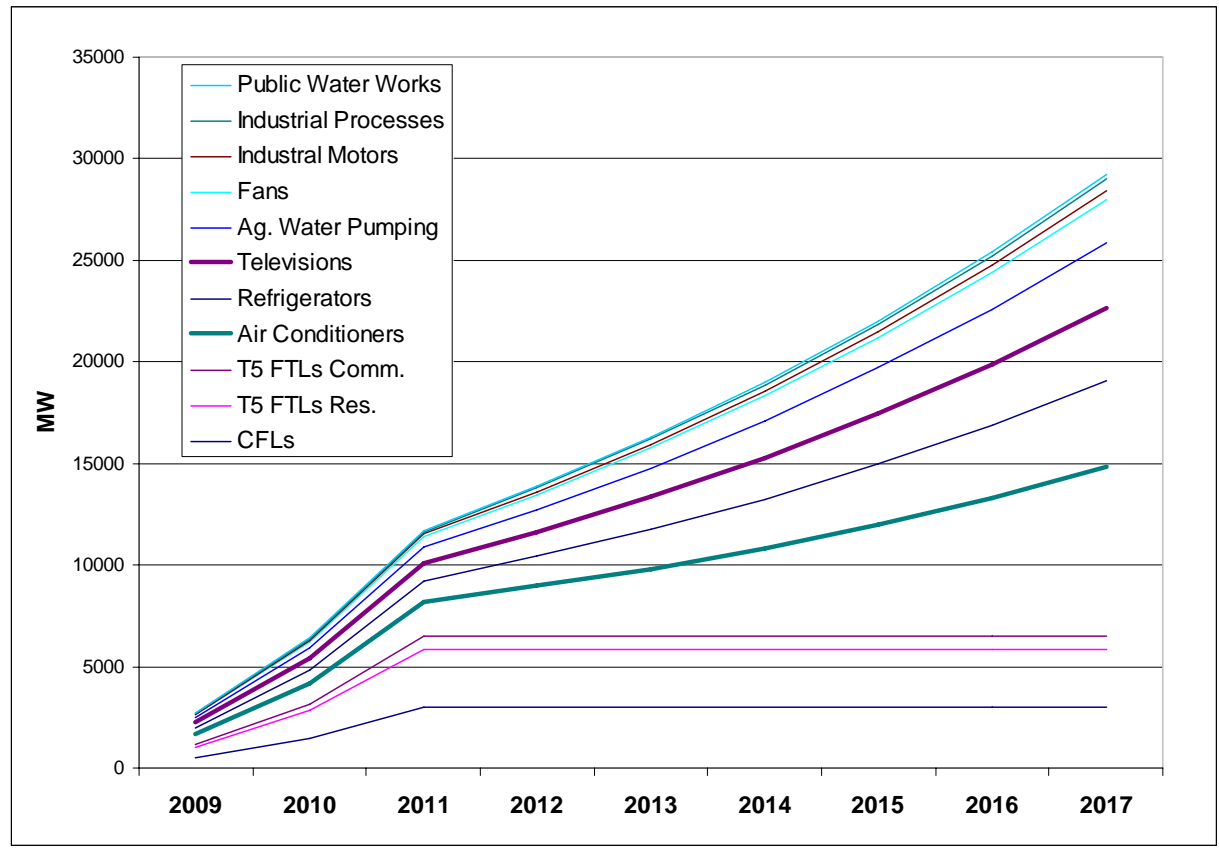

The aggregate cost-effective savings potential in the SEE scenario adds up to about 25 GW by the end of the $12^{\text {th }}$ Five Year Plan (Figure 7). The potential varies by end-use over time. The largest potential savings are related to improvements in lighting technologies, accounting for almost $43 \%$ of total peak load reduction, which rises to 55\% 
by 2011 (Figure 7). The lighting share declines subsequently compared to that for other end uses as all new lighting is assumed to shift to efficient devices. Air conditioners (ACs) constitute the next best option due to the rapid increase in their penetration over the study period. ACs account for $18 \%$ of the savings potential to begin with and eventually reach $25 \%$ by the end of the $12^{\text {th }}$ Five Year Plan or about the same proportion as lighting. Refrigerators, televisions and agricultural water pumping constitute the next three savings potentials in this scenario followed by industrial loads and public water works.

Figure 8 shows the corresponding electricity savings potential over the same period. The proportion of electricity savings varies from that for peak-load savings described above. The variation occurs due to the fact that the usage of end-use technologies does not necessarily peak during the evening peak load hours. In the case of lighting, the peak occurs at the same time as the overall system peak and hence the proportion of electricity savings is about the same as that for peak load savings. On the other hand, agricultural pumping occurs largely at off-peak hours and the electricity savings potential is thus much larger, about $25 \%$ compared to only $6 \%$ reduction in peak load savings.

Figure 8: Electricity Savings Potential

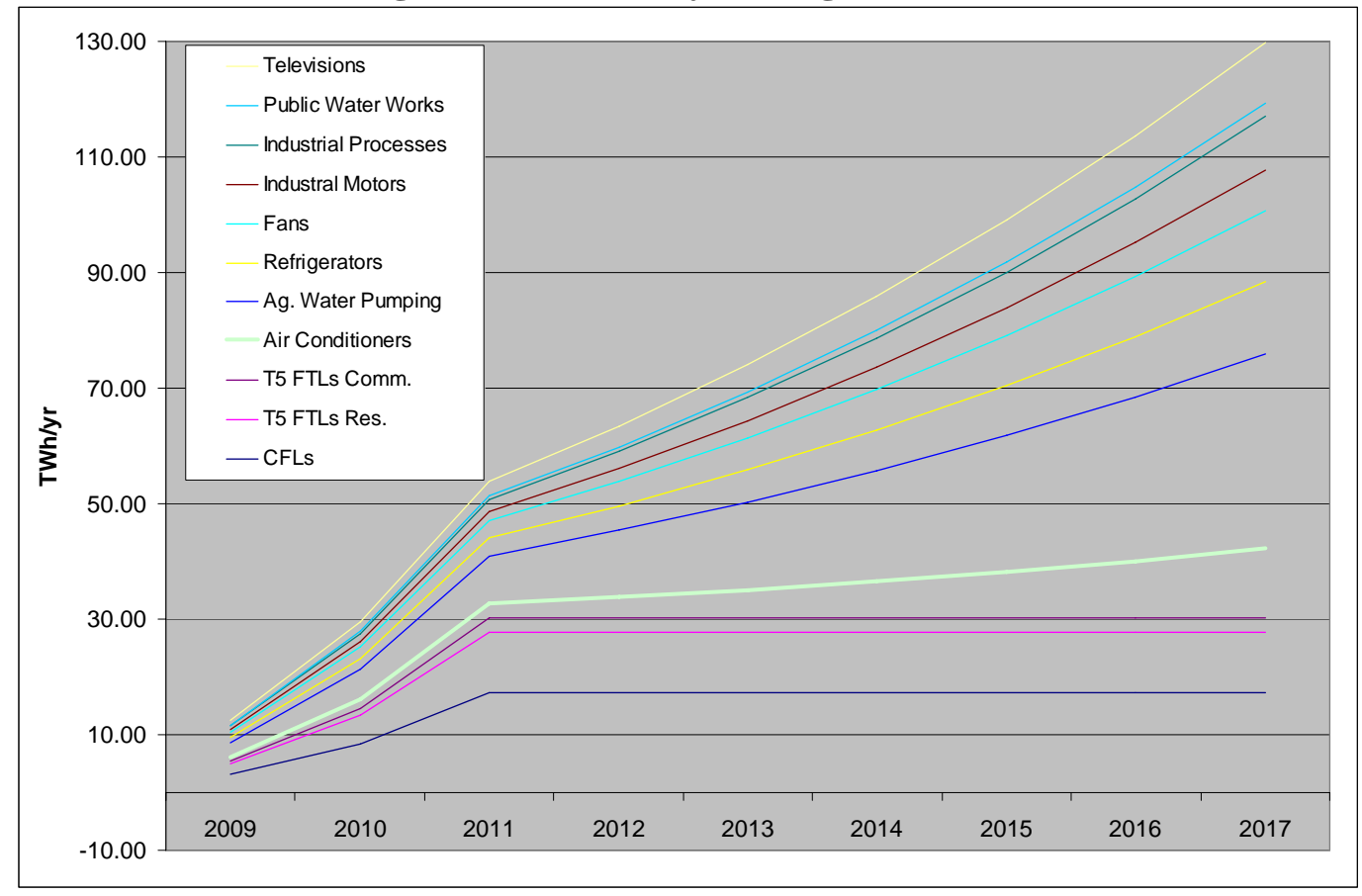

Figure 4 shows the benefit of rapid penetration of the energy efficient end-uses. The peak-load deficit is eliminated by 2012 due to the rapid deployment of lighting technologies and the steady increase in penetration of the other efficient technologies. Figure 10 illustrates the parallel case for electricity supply and demand between 2009 and 2017. In this case, the electricity deficit is eliminated by 2014. A key difference between the peak load and electricity deficits is that the higher penetration of efficiency options 
results in earlier elimination of the power deficit and also in an increasing reserve margin by 2017 (Figure 4) compared to that for electricity generation (Figure 10). This occurs because of the higher percentage of electricity deficit in the base year (13.3\%) compared to a peak-load deficit of $10.8 \%$. Also, some of the end uses such as lighting run on peak and hence improving their efficiency contributes significantly to peak load reduction and to reduction in the need for supply capacity while others such as agricultural water pumping have the opposite effect. The combined effect of the end uses selected for the SEE scenario, however, is that these are somewhat but not significantly more effective in reducing peak load compared to reducing electricity consumption.

Figure 9: Business as Usual (BAU) Scenario 1 Electricity Demand and Availability

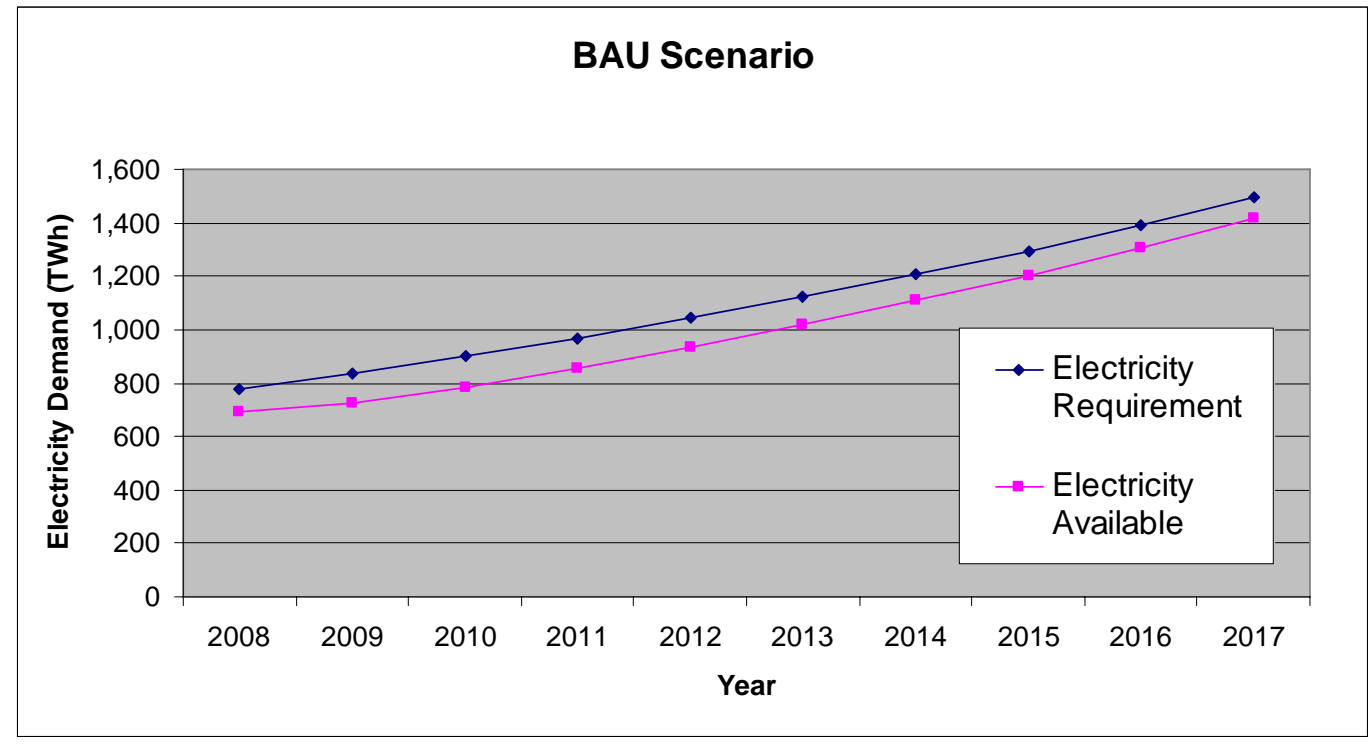

Figure 10: Supply with Energy Efficiency (SEE) Scenario 2Electricity Demand and Availability

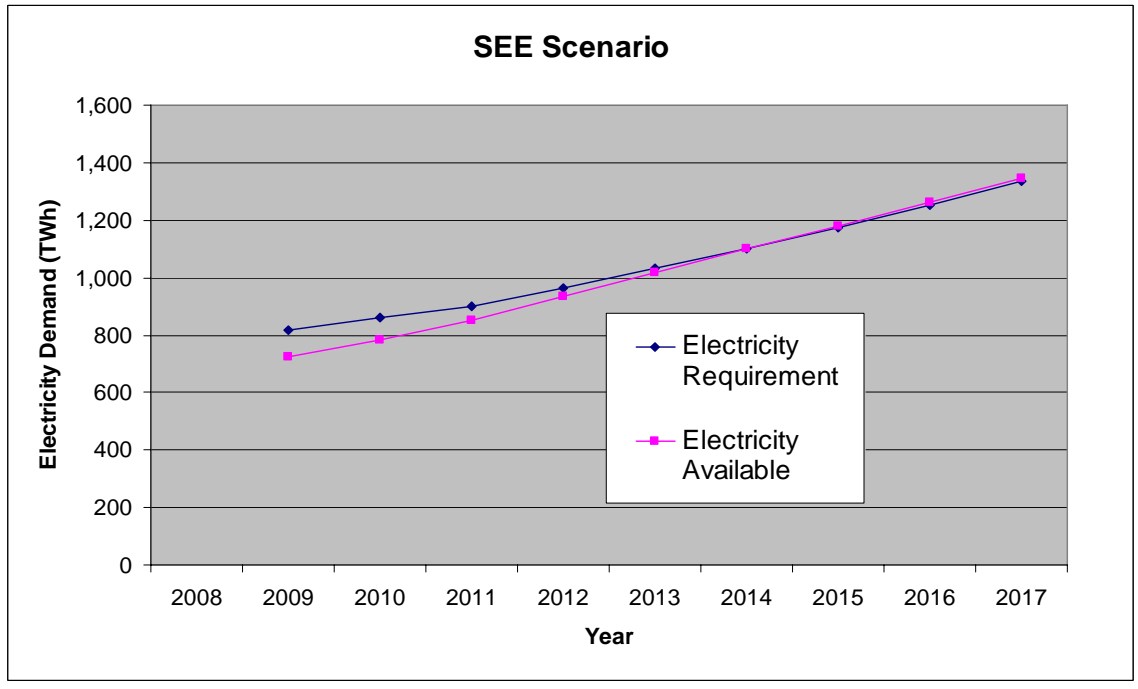




\section{Economic Benefits, and Fuel and $\mathrm{CO}_{2}$ Savings}

In this section, we report on the economic benefits associated with the higher penetration of energy efficiency measures in SEE Scenario 2. The benefits occur due to the decreased power capacity and generation of electricity in the second scenario that lowers the investment and fuel costs respectively. The major benefit, however, comes because of the removal of electricity shortage in this scenario. The higher penetration of energy efficient equipment lowers the demand for electricity. The allocation of electricity thus saved is then adequate to eliminate the electricity shortage and the portion supplied to business customers leads to a significant increase in economic output, which we quantify below.

The investment required for the SEE scenario includes that for building new power plants and for increased penetration of energy efficient devices. Since the amount of capacity to be built in the SEE scenario is less than that in the BAU scenario the investment required amounts to $\$ 74.2$ billion compared to $\$ 81.4$ billion in the BAU scenario. In addition, the investments needed for efficient devices amounts to $\$ 6.3$ billion. The total investment needed in the SEE scenario is thus $\$ 80.5$ billion, which is only slightly less than that in the BAU case. The major benefit is thus derived from the reduced operating and fuel costs, and the benefit derived from the increased economic output, which would result from supply of electricity that fully satisfies demand.

\subsection{Capital, Variable Cost, Fuel, and $\mathrm{CO}_{2}$ Savings}

The reduction in electricity generation begins once the electricity shortage is removed in 2014, and accelerates thereafter. The cumulative electricity generation in Scenario 2 is thus lower than in Scenario 1 by 81 TWh by the end of the $12^{\text {th }}$ Five Year Plan and by 411 TWh by 2020 .

Table 7: Cumulative Benefits of SEE Scenario Compared to BAU Scenario

\begin{tabular}{|l|r|r|}
\hline & $2009-2017$ & $2009-2020$ \\
\hline Electricity Generation Savings (TWh) & 81 & 411 \\
\hline Reduction in $\mathrm{CO}_{2}$ Emissions (Million tons) & 65 & 333 \\
\hline Reduction in $\mathrm{SO}_{2}$ Emissions (Thous. tons) & 410 & 2,100 \\
\hline Reduction in $\mathrm{NO}_{\mathrm{x}}$ Emissions (Thous. tons) & 410 & 2,100 \\
\hline Reduction in Fly Ash SPM Emissions (Thous. tons) & 120 & 600 \\
\hline Imported Coal Savings (Million tons) $^{\prime}$ & 36 & 186 \\
\hline Operational Cost Savings (US \$ Billions) $^{+}$ & 2.2 & 11.0 \\
\hline Increase in GDP (2007 US \$ billions) $^{+}$ & $\$ 505$ & $\$ 608$ \\
\hline
\end{tabular}

Note: +Values are based on an estimated 23\% of C\&LV-MV customers using self-generation and inverters in 2009 with the share increasing to $48 \%$ by 2020 .

In 2008-09, coal accounted for $69 \%$ of the generation from conventional sources and gas accounted for another 13\%. Hydro and nuclear accounted for the remaining $16 \%$ and $2 \%$ respectively (CEA, 2009). Allocating the 81 TWh difference in generation as per these percentages and multiplying the results by the generation cost estimates in Table 2 
results in total savings in operational (including fuel) costs of power plants of \$2.2 billion by 2017 and $\$ 11$ billion by 2020 (Table 7).

In addition to monetary savings, this reduction in generation through efficiency improvements entails significant reduction in $\underline{\mathrm{CO}}_{2}$ emissions. The $\mathrm{CO}_{2}$ emissions factor for the Indian electricity system is 0.79 tons of $\mathrm{CO}_{2}$ per MWh of electricity (CEA, 2008). Thus, the cumulative $\mathrm{CO}_{2}$ abatement in Scenario 2 by the end of $12^{\text {th }}$ Five Year Plan is 65 million tons, which increases to 333 million tons by 2020 .

The reduced generation will also result in a decrease in emissions of local pollutants $\left(\mathrm{SO}_{2}, \mathrm{NO}_{\mathrm{x}}\right.$, and Fly Ash) that are noted in the table. These values are calculated based on the estimated power plant specific emissions reported in a publication by Ohio State University ${ }^{7}$. Typically the sulfur content of Indian coal is quite low $(\sim 0.5 \%)$ and hence the emissions savings tend to be small as well.

Estimates of per-unit fuel consumption from Table 3 imply import reductions of 36 and 186 million tons of coal by 2017 and 2020 respectively. These figures may be compared with about 23 Mt of coal imported in 2006-07. These savings would help improve India's energy security position.

\subsection{Macro-economic Impacts: GDP Benefit}

The most significant economic impact accrues from removal of the electricity deficit to the Indian economy and the allocation of the saved electricity to business customers, and not from the difference in distribution of the investment or the operational savings between the two scenarios ${ }^{8}$.

The electricity saved through energy efficiency improvements in Scenario 2 is allocated among the electricity constrained domestic, commercial, and LV\&MV industrial sectors. The proportions of electricity consumption among these sectors are estimated beginning in 1991 and are shown in Figure 11 below. The commercial sector share has continued to increase and reached $22.4 \%$ by $2007-08$ while that of the LV-MV industrial sector declined to $19.6 \%$. Projecting these trends to 2019-20 reveals that the two shares will change considerably with the commercial share increasing to $35 \%$ and the other declining to $13.5 \%$. We use these proportions to determine the changes in electricity demand over these periods.

\footnotetext{
7 Anthropogenic Emissions from energy activities in India: Generation and Source Characterization. http://www.osc.edu/research/archive/pcrm/emissions/thermalemissions.shtml

${ }^{8}$ Since we assume that all other factors of production except electricity are present, we do not calculate the additional employment creation due to removal of the electricity deficit. In reality, the large projected increases in the LV-MV industrial and commercial sectors would entail increased indirect job opportunities but we do not estimate this effect.
} 
Figure 11: Commercial and LV-MV Industry Electricity Shares

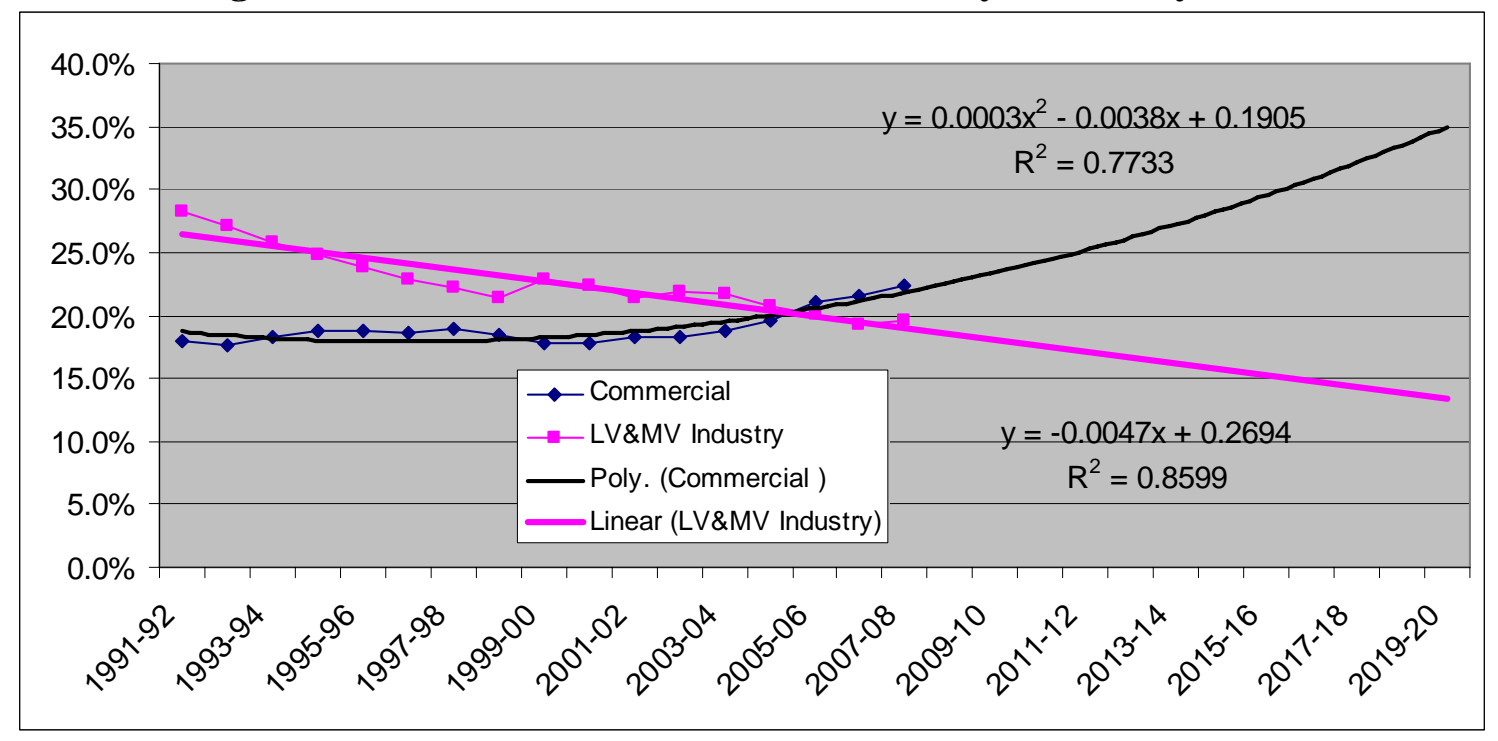

The reallocated saved electricity to the commercial and LV-MV industrial sectors increases their output by allowing them to operate at full capacity. The amount of increase in output depends on the kinds of industries or businesses that benefit from the increase in electricity service. We estimate the increase in economic output based on the average electricity productivity in the concerned sector. The proportional increase in economic output also depends on whether or not these industries/businesses have self-generation capacity in the absence of electricity supply from the grid. We adjust our estimates of economic output to account for selfgeneration in the LV-MV sectors.

The electricity productivity of the commercial sector ${ }^{9}$ is calculated by dividing the total contribution to GDP from the commercial sector by the total annual electricity consumed by this sector annually from 1991 to 2020 (Figure 12).

\footnotetext{
${ }^{9}$ We assume that all commercial loads are supplied by LV supply.
} 
Figure 12: Electricity Productivity

(Commercial and LV-MV Industrial Sectors and Overall Economy)

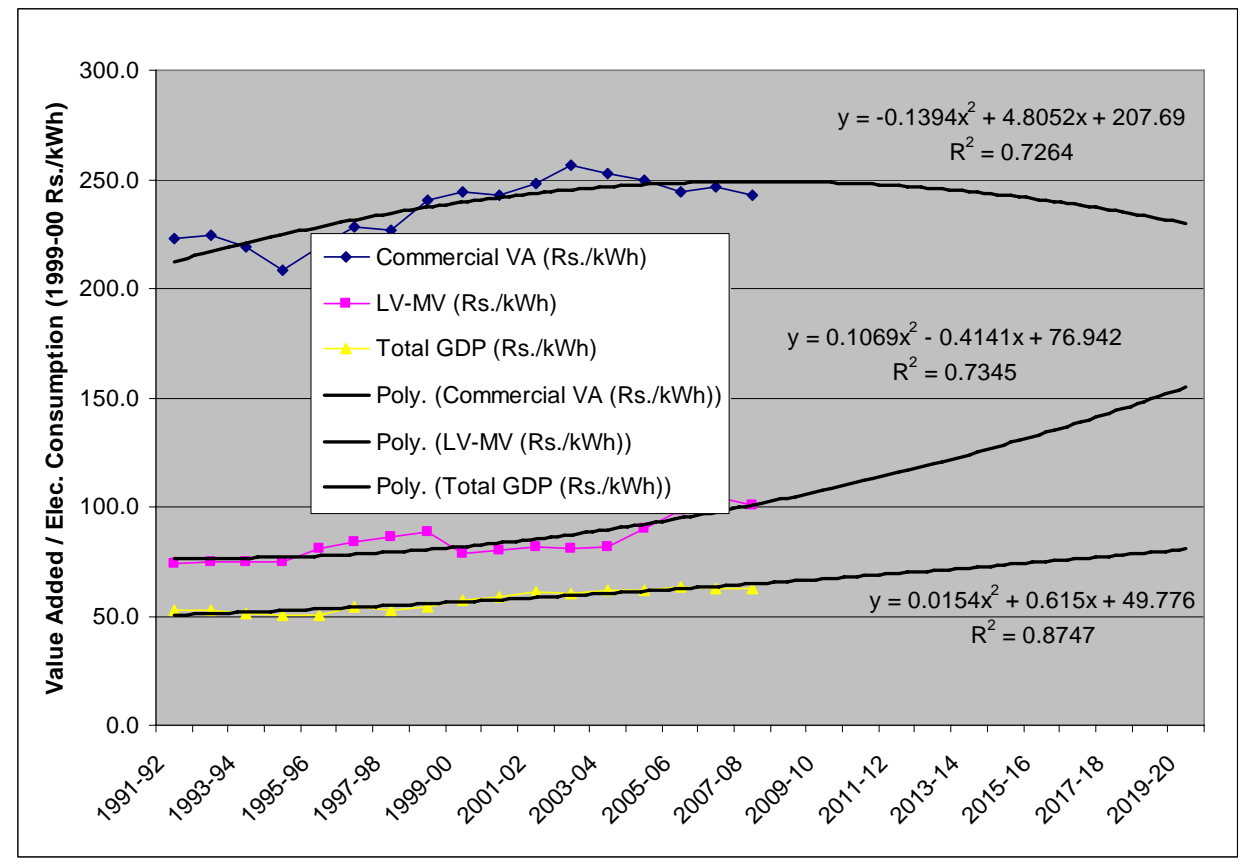

This analysis produces an interesting result. The electricity productivity in both commercial and LV-MV industrial sectors has increased during the study period, and productivity of the former is several times that of the latter sector. The electricity productivity of the commercial sector has flattened out with a slight decline in this value since 2004 perhaps due to increased use of air conditioning in new buildings, while that in the latter sector has continued to increase. The productivity of the total economy too has improved somewhat during the study period and the trend indicates that it will continue to increase in the future.

The cumulative electricity consumption deficit amounts to 654 TWh from 2009-2017 in the BAU scenario. Since the energy efficiency options are implemented through replacement and new sales the electricity deficit is removed gradually in the SEE scenario over the study period. As a consequence, deficit amounting to a cumulative total of 199 TWh persists until 2014 in the SEE scenario. The net amount of deficit that is removed thus is the difference between the two or $455 \mathrm{TWh}$.

Removal of this deficit provides a significant benefit to economic output in the commercial and LV-MV industrial sectors. We estimate this benefit by using the aforementioned direct productivity factors. We assume that the deficit is in the same proportion as the projected electricity shares of the commercial and LV-MV industrial sector as shown in Figure 11. Assuming that the consumptive domestic sector does not reinvest the resultant monetary savings, we concentrate on the increase in production in the productive (commercial and LV-MV industrial) sectors owing to this increase in electricity availability. The discounted present value of this increase in production 
amounts to $\$ 609$ billion in the commercial sector and $\$ 189$ billion in the LV-MV industrial sectors for a total benefit of $\$ 798$ billion by 2017. This is equivalent to roughly 88\% of India’s 2007-08 GDP of \$911 billion.

As noted earlier, some of commercial and LV-MV businesses rely on self generation to offset the grid electricity deficit. Unfortunately, there are no explicit data on the proportion of self-generation in these sectors. There are some studies that report on the percentage of self generation. Bose et al. (2000) report from empirical data that $20 \%$ of businesses self generate in the state of Gujarat. Nationally, data from sales of small $(<1$ MW) generators (CEA 2005) stretching back to 1991 provide some insights in the current availability of self-generators. Assuming a 5\% retirement rate from 1991-2009 we estimate the total 2009 self-generation capacity to be $26.1 \mathrm{GW}$. By itself, if all this capacity were spread across the 21 million commercial (C) and LV-MV industrial customers (CEA, 2009), and further if all the capacity were used at the evening peak hours, it would be more than enough to take care of the estimated 2009 power shortage of about $13.1 \mathrm{GW}$ or 0.6 watts/customer.

However, the same data set shows that the total number of customers with generator sets is about 917 thousand or $4.7 \%$ of the total C\&LV-MV customers $^{10}$, The electricity shortage prevails in every state in India, thus assuming that the generators are spread in the same proportion as the peak shortage across the states, and that all of them are used to address the evening peak, implies that only $567 \mathrm{MW}$ or $4.3 \%$ of the total shortage is being addressed.

Another option that many customers utilize is the use of inverters to ensure uninterrupted power supply (UPS). UPS is widely used in both residential and commercial sectors. Recent data shows that the sales of UPS devices have increased faster than those of generators and reached about 1.2 million in 2009 (Indiastat 2010). The total number of UPS devices in 2009 is estimated to be 5.9 million assuming a 5\% retirement rate. A large fraction of these devices are held by domestic users and also by the organized sectors. If we assume that about $75 \%$ of these devices are held by C \&LVMV customers then combined with the generator sets they would add up to 4.4 million customers. ${ }^{11}$ The total amounts to $3300 \mathrm{MW}$ or $25 \%$ of the total shortage being addressed by these generators and UPS devices combined.

There are two reasons why this value may be low. One is that LV-MV industrial businesses may shift batch production to other times of the day, and two there may be variation in peak load shortage and the location of C\&LV-MV customers. On the other hand, use of self-generators and inverters to offset deficits during off peak hours may

\footnotetext{
${ }^{10}$ Not all the 917 thousand generator sets are owned by C\&LV-MV customers. We assume they are in order to arrive at a conservative estimate of the GDP impact.

${ }^{11}$ Often businesses own both generator sets and inverters (Wartsila 2009), but in order to make a conservative estimate of the GDP impact we assume that these are owned by separate customers and both are equally effective in reducing the deficit.
} 
increase the estimated value. ${ }^{12}$ Further, inverters have a low efficiency with $25 \%$ or more losses. As a result, while inverters permit owners to maintain their business activity, their usage adds to the overall electricity shortage.

Figure 13: Inverter and Generator Stock : Historical and Projected
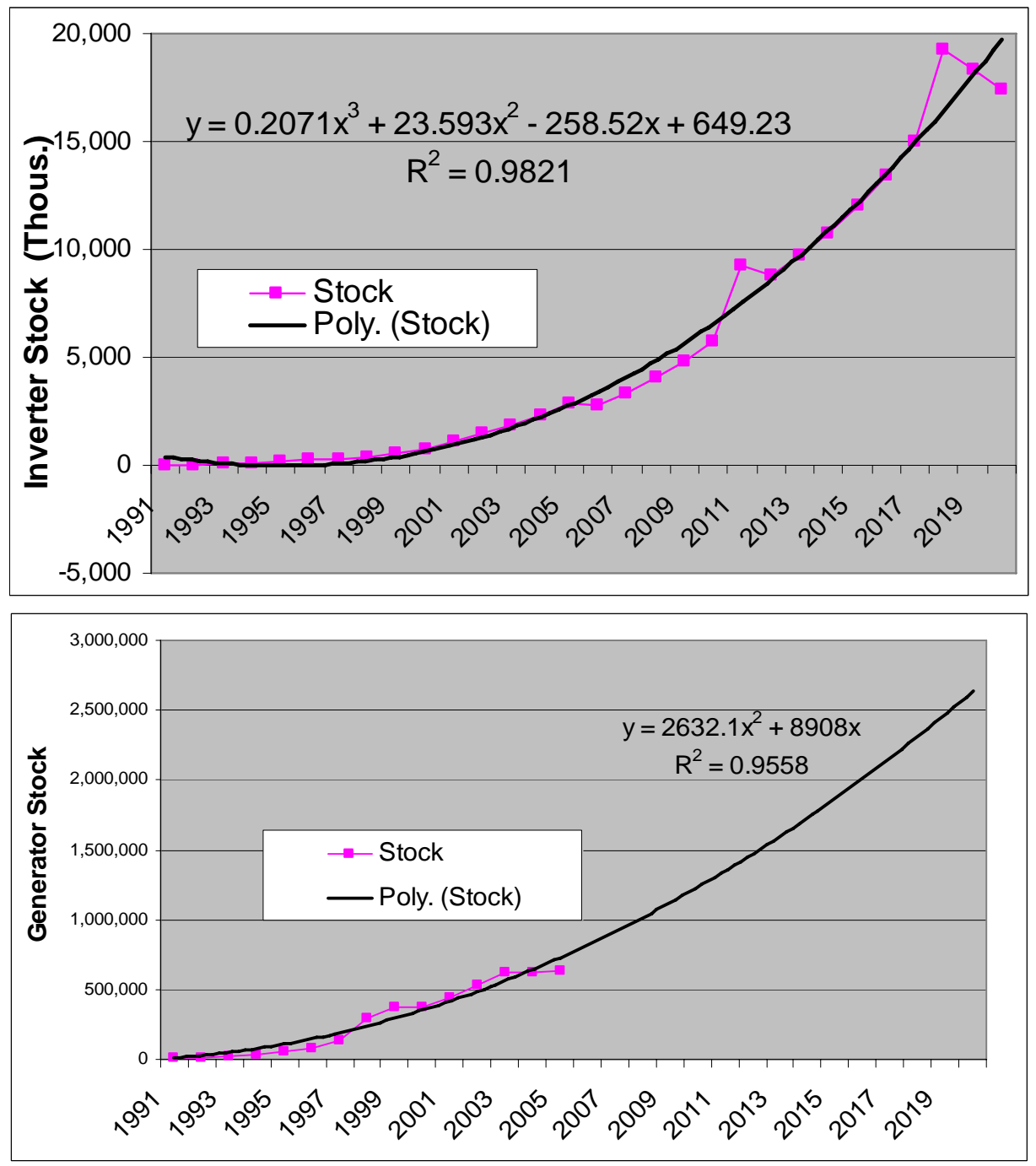

Figure 13 shows the increase in the use of inverters and generators over time. We project the sales trends for generators during between 1991 and 2006 up to 2020. For inverters, we use projections made by Indiastat (2010) up to 2020 to capture the change in annual stock until that year. In both generator and inverter trends, we assume a $5 \%$ retirement rate per device, and for inverters we assume that $75 \%$ of these devices are used

12 One riddle that remains unanswered is the cost of self-generators that we estimate ranges from Rs.1015/kWh short term costs to Rs. 20-30/kWh long-run costs that include the cost of capital equipment. What fraction of industries find this cost high enough to affect their profits significantly enough so as dissuade them from purchasing self-generators? 
in the C \& LV-MV categories of customers. The outcome of this calculation is that the percentage of customers who rely on generators and inverters to offset electricity shortages rises from $23 \%$ in 2009 to $48 \%$ by 2020 . We further make a conservative assumption that through the use of these devices customers are able to fully recapture the output losses that electricity cuts would have imposed on them. As a consequence our aforementioned estimated cumulative GDP benefit is reduced to \$505 billion by 2017 and \$608 billion by 2020 .

\section{Limitations of the analysis}

The analysis is intended to provide insights into the role that energy efficiency could play in reducing or removing the electricity deficit in the Indian economy, and thus it has lessons for other developing economies that too face a chronic electricity deficit. It highlights the large GDP benefits that could accrue to the Indian economy by removing electricity deficits. Since the analysis is conceptual, it overstates the case in some respects while undercounting some of the macroeconomic benefits of such a strategy.

In the SEE Scenario 2, energy efficiency improvements are targeted at only sales of new equipment. However, energy efficiency measures may not achieve the technoeconomic potentials illustrated in the SEE Scenario 2 unless policies such as labels and standards for mass market goods and nationwide DSM programs are put in place. What types of specific incentives are needed to accelerate the penetration of these measures? To what extent might these increase penetration over a reference case? How well do we understand the reference case? What other opportunities in energy efficiency could surface over the analysis period? Questions such as these will determine the level of savings actually achieved in the SEE Scenario 2. Improved modeling, data collection and the potential for implementation of efficiency policies will be needed to address these questions.

Bulk of the investment in production of energy efficiency equipment is expected to come from private industry while that for the supply-side will likely originate from the government. Analysis is needed to estimate the detailed investment potential in each case, and the incentives that might be needed to promote each type of efficiency improvement.

Another set of questions arises from the modeling of the supply side, where we have assumed a single supply source. Obviously, this is not the case, and the Indian power sector has coal, oil/diesel, natural gas, nuclear, hydro, and several renewable generation sources, each with a different construction lead time. Similar to the electricity efficiency penetration case, one would need to model these by year over a ten-year scenario since the investments will be spread over the construction schedule and some of these will take place for plants that will come on line after 2020. In addition, some degree of representation is needed for peak and base plants since their capital costs are different.

While the above consideration of the energy efficiency and power plant disaggregation and timing may slow the removal of deficits, and hence reduce the economic impact over the period to 2020, the impacts on government budgets, which we 
have not analyzed here, constitute a yet another strong case for the removal of the electricity deficit. The major impact on government current account revenue would come from the reduction in subsidy payments to the agricultural sector. The government would save in two ways, one by not having to finance the construction of as many new power plants as in the BAU Scenario, and secondly by the increased tax revenue it would collect from the larger business activity in the SEE scenario.

\section{Summary and Conclusions}

This paper highlights the significant role that energy efficiency measures could play in alleviating India's electricity deficit. Cost-effective end-use electricity efficiency measures have the potential to eliminate the expected electricity deficit by 2014 while at the same time requiring less investment for new power supply compared to the BAU scenario. Removal of the electricity deficit through these means leads to a $\$ 505$ billion and $\$ 608$ billion increase in India's economic output by 2017 and 2020 respectively based on the use of self-generators and inverters by $23 \%$ of the deficit-affected businesses in 2009, which increases to $48 \%$ by 2020 . It would also reduce government outlay for power capacity expansion and subsidy payments to India's state-run electric utility companies. India's energy security position would also improve due to reduced coal imports for electrical energy generation in the efficiency scenario, and it would lead to climate change mitigation by reducing carbon dioxide emissions by $333 \mathrm{Mt}$ of $\mathrm{CO}_{2}$ by 2020.

An important conclusion from our analysis is that the LV-MV industrial sector and the commercial sector, which along-with the domestic sector usually experience electricity cuts during times of shortage, are more productive per unit of electricity consumption than the overall national average. Thus, the Indian economy would greatly benefit if the electricity shortages in the more productive LV-MV industrial and commercial sectors were removed quickly.

A more detailed analysis would need to improve the representation of electricity supply technologies and peak- and base-load power demand, better estimate the rate of market penetration and the market potential for energy efficiency measures, estimate the quantitative tax benefit to the state and central governments, and highlight the policies needed to promote electricity efficiency improvement.

Acknowledgements: The authors would like to thank Dr. Amol Phadke, LBNL and Nikit Abhyankar, Stanford University for providing insightful technical inputs and data on generators and inverters, Shakti Sustainable Energy Foundation for organizing presentations in US and India, Soumen Biswas, CEA for providing access to and explaining CEA data definitions, Daljit Singh and Gayatri Gadag, Prayas Energy Group for sharing their report on efficiency potential and costs, and collating historical data on value added and electricity consumption by sectors respectively, and Prof. Jim Sweeney, Stanford University for a very helpful review and suggestions for modifying the macroeconomic analysis. Any errors or omissions in the document are the responsibility of the author and should not to be attributed to the contributors. 


\section{REFERENCES}

Bakshi, A. S., Central Electricity Authority (2008). Power Scenario in India. Available at http://www.energymanagertraining.com/PowerPlantComponent/PresentationsPPC/NPTI30Sep-1Oct2008/1_2PowerScenarioinIndia.ppt (accessed June 01, 2009).

Barry, J. A., Alliance to Save Energy (2007). WATERGY: Energy and Water Efficiency in Municipal Water Supply and Wastewater Treatment. Available at http://www.watergy.org/resources/publications/ (accessed July 9, 2009).

Bose, R. K. and Shukla, M. (2000). Electricity Tariffs in India: An Assessment of Consumers' Ability and Willingness to Pay in Gujarat. Energy Policy 29 (2001) 465478.

Bureau of Energy Efficiency (BEE) (2007). Energy Conservation and Efficiency, DSM Initiatives in India. Available at www.indiaenergyforum.org/ipf/pres110907/BEE.ppt (accessed June 2, 2009).

Central Electricity Authority (CEA) (2005). Generator ( $<1 \mathrm{MW})$ sales data available at http://www.cea.nic.in/planning/Tapping\%20of\%20Surplus\%20Power\%20from\%20C aptive\%20Power\%20Plants/Appendix\%20to\%20report\%20on\%20CPP.htm (accessed March 12, 2010).

CEA (2006). All India Electricity Statistics - General Review 2006. Available at http://www.cea.nic.in/power_sec_reports/general_review/0405/index.pdf (accessed June 13 2009).

CEA (2006a). $17^{\text {th }}$ Electric Power Survey of India.

CEA (2009). Monthly review of power sector (executive summary) for the month of April 2009, page 11.

CEA (2009a). Monthly review of power sector (executive summary) for the month of April 2009, pages 34-40B.

CEA (2009b). Project monitoring reports available at http://www.cea.nic.in/ (accessed June 5, 2009).

de la Rue du Can, S., McNeil, M. and Sathaye, J. (2009). India Energy Outlook: End Use Demand in India to 2020, LBNL Report\# 1751E. Available at http://ies.lbl.gov/publications (accessed July 9, 2009).

Deneb Consultants (2002). Background Paper for the Conference on Strategies for Energy Conservation in the New Millennium, August 23-24, 2002, New Delhi, India. Prepared for FICCI and sponsored by USAID, Delhi.

Dutt, G., Asian Development Bank (1991). Energy End Use: An Environmentally Sound Development Pathway. ISBN: 971-561-013-7. 244 pp.

Economic Survey of India 2007-08. Available at www.indiabudget.nic.in (accessed May 19, 2009)

Gas Authority of India Limited (GAIL) (2009). Customer Zone: Power. Available at http://www.gailonline.com/customerzone/power.htm (accessed July 15, 2009). 
Indiastat. Market Forecast for UPS and Stabilisers. Retrieved March 11, 2010, from indiastat.com commercial database http://www.indiastat.com/table/marketforecast/10143/electricalsandaccessories/10388 /10390/data.aspx)

Ministry of Power (2007). Report of The Working Group on Power for Eleventh Plan (2007-12), Volume -II, Main Report. Available at http://www.scribd.com/doc/4378284/The-Working-Group-of-Power-for-EleventhPlan200712 (accessed July 14, 2009).

Ministry of Power (2007a). Report on 17th Electric Power Survey of India. Available at http://www.powermin.nic.in/generation/pdf/17th\%20EPS.pdf (accessed July 14, 2009).

Ministry of Power (2008). Annual Report. Available at http://www.cea.nic.in/...us/Annual\%20Report/2007-08/annual_report_07_08.pdf (accessed July 20, 2009).

Natarajan, B. (2008). EE Finance in India - Some Progress and What Next? Presented at the Asia Clean Energy Forum in Manila, 3-5 June 2008. Available at http://www.adb.org/Documents/events/2008/ACEF/Session17-Natarajan.pdf (accessed April 24, 2009).

Planning Commission (2002). Tenth Five Year Plan, Government of India, New Delhi, India.

Planning Commission (2008). Eleventh Five Year Plan, Government of India, New Delhi, India.

Prayas Energy Group (2009). Energy Saving Potential in Indian Households from Improved Appliance Efficiency

Ramana, M.V., D’Sa, A. and Reddy, A.K.N. (2005). Economics of Nuclear Power from Heavy Water Reactors. Economic and Political Weekly, April 23, 2005, pp 17631773.

Rediff Business (2009). How to Deal With India’s Fiscal Deficit. Available at http://business.rediff.com/column/2009/apr/16/bcrisis-how-to-deal-with-indias-fiscaldeficit.htm (accessed July 4, 2009).

Sathaye J., J. Roy, R. Khaddaria and S. Das, (2006) Reducing Electricity Deficit through Energy Efficiency in India: An Evaluation of Macroeconomic Benefits, LBNL 59092. Accepted for presentation at the Fifteenth International Input-Output Conference, June 27 - July 1, 2005, Renmin University, Beijing, China. (Available upon request)

World Resources Institute (WRI, 2009). POWERING UP: The Investment Potential of Energy Service Companies in India. ISBN: 978-1-56973-717-0. 